NBER WORKING PAPER SERIES

\title{
DO STOCK PRICES INFLUENCE CORPORATE DECISIONS? EVIDENCE FROM THE TECHNOLOGY BUBBLE
}

\author{
Murillo Campello \\ John Graham \\ Working Paper 13640 \\ http://www.nber.org/papers/w13640 \\ NATIONAL BUREAU OF ECONOMIC RESEARCH \\ 1050 Massachusetts Avenue \\ Cambridge, MA 02138 \\ November 2007
}

We thank Heitor Almeida, Nittai Bergman, Markus Brunnermeier, Judy Chevalier, Long Chen, Martijn Cremers, Dirk Hackbarth, Eliezer Fich, Antônio Galvão, Vidhan Goyal, Robin Greenwood, Cam Harvey, Massimo Massa, Joel Peress, Paul Tetlock (our WFA discussant), Selim Topaloglu, Mike Weisbach, and Jeff Wurgler for their useful suggestions. Comments from seminar participants at INSEAD, Michigan State University, MIT, Ohio State University, Queen's University, University of Toronto, Washington University in St-Louis, Yale University, and the 2007 WFA meetings are also appreciated. Marek Jochec and Bruno Laranjeira provided excellent research assistance. We are responsible for all remaining errors. The views expressed herein are those of the author(s) and do not necessarily reflect the views of the National Bureau of Economic Research.

(C) 2007 by Murillo Campello and John Graham. All rights reserved. Short sections of text, not to exceed two paragraphs, may be quoted without explicit permission provided that full credit, including $\odot$ notice, is given to the source. 
Do Stock Prices Influence Corporate Decisions? Evidence from the Technology Bubble Murillo Campello and John Graham

NBER Working Paper No. 13640

November 2007

JEL No. G31

\begin{abstract}
$\underline{\text { ABSTRACT }}$
Do firms issue stock when prices seem irrationally high? Do they invest or save the proceeds from the sale of overvalued stocks? Is value created or destroyed in the process? This paper uses a novel identification strategy to tackle these questions. We examine the capital investment, stock issuance, and cash savings behavior of financially constrained and unconstrained non-tech manufacturers ("old economy firms") around the 1990's technology bubble. Our results suggest that, because they relax financing constraints, high stock prices affect corporate policies. In particular, during the bubble, constrained non-tech firms issued equity in response to mispricing and used the proceeds to invest. They also saved part of those funds in their cash accounts. We do not find similar patterns for unconstrained non-tech firms, neither for tech firms. Our findings do not support the notion that managers systematically issue overvalued stocks and invest in ways that transfer wealth from new to old shareholders, destroying economic value. Rather, our evidence implies that what appears to be overvaluation in one sector of the economy may have welfare-increasing effects across other sectors.
\end{abstract}

\author{
Murillo Campello \\ University of Illinois at Urbana-Champaign \\ Department of Finance \\ 430A Wohlers Hall, MC-706 \\ 1206 South Sixth Street \\ Champaign, IL 61820 \\ and NBER \\ campello@uiuc.edu \\ John Graham \\ Duke University \\ Fuqua School of Business \\ One Towerview Drive \\ Durham, NC 27708-0120 \\ and NBER \\ john.graham@duke.edu
}




\section{Introduction}

Financial economists have increasingly cast doubt on the view that market prices efficiently reflect fundamental firm values. While most of the literature emphasizes the asset pricing implications of market misvaluation, few studies look at whether mispricing has real-side consequences. In a seminal article, Fischer and Merton (1984) argue that managers should take advantage of irrationally low discount rates for their firms' equity by issuing stocks and investing the proceeds. Subsequent studies by Morck et al. (1990), Barro (1990), Blanchard et al. (1993), Galeotti and Schiantarelli (1994), Chirinko and Schaller (1996), and Lamont (2000), among others, test the idea that stock market fluctuations affect firm investment over and above fundamentals. Using mostly aggregate data, these studies report mixed results. Morck et al. and Blanchard et al., for example, argue that the "irrational" component of stock valuation does not affect real investment. In essence, they find that the component of prices that is not summarized by standard proxies for the marginal product of investment (e.g., profitability and sales growth) fails to explain corporate spending. In contrast, Barro and Galeotti and Schiantarelli, find explanatory power in the irrational component of prices. ${ }^{1}$

Whether stock prices influence the real economy becomes a relevant concern when markets experience price bubbles. In the face of widespread mispricing, it can be rather difficult for arbitrageurs to bring values back to fundamentals (see Morck et al. (1990)). Arbitrage trading is a risky, costly activity, and in a world where traders have limited resources, mispricing may emerge and quickly spread across different securities and sectors (Shleifer and Vishny (1997)). Crucially, firms have a natural monopoly over the supply of new securities. In this context, a number of questions arise: Do corporate managers take advantage of mispricing during bubbles? If so, what do firms do with the proceeds from the sale of overvalued stocks? Do they save or invest? Is value created or destroyed in the process? The answers to these questions can shed light on the economic consequences of market (mis)valuation.

When managers work in the best interest of shareholders, the Fischer-Merton argument goes, they should sell their firms' stocks whenever equity is "overvalued." Managers should do so even when their private assessment of investment productivity is lower than that of investors. As discussed by Blanchard et al. (1993), one problem with this arbitrage argument is that the sale of overvalued stocks may benefit only current shareholders. To wit, at the rational cost of funds, the marginal investment has a zero NPV. Issuing overvalued stocks and investing the proceeds destroys value, as additional investment drives the marginal product of capital below optimal levels. As old shareholders sell their positions, new shareholders are made worse off by paying a high price for stakes in firms that, on the margin, will invest in negative NPV projects. Unless new shareholders, too, expect to

\footnotetext{
${ }^{1}$ More recent papers use direct, ad hoc proxies for mispricing (based, e.g., on discretionary accruals, momentum returns, and analysts' forecasts) and argue that those proxies affect investment (see Polk and Sapienza (2003) and Gilchrist et al. (2005)). Proxies for price informativeness have also been found to affect investment (Chen et al. (2006)).
} 
sell overvalued stocks in the future (a "rational bubble"), managers will have conflicting incentives when selling overvalued stocks (see also Stein (1996)). ${ }^{2}$ Alternatively, managers could issue overvalued stocks and invest the proceeds in cash and interest-bearing securities ("zero-NPV projects"). However, this poses another problem: investors may burst the price bubble if they observe firms allocating the proceeds from new issues into savings as opposed to capital acquisition. It follows that not only might bubbles influence firm investment, but firm investment might also influence bubbles.

This discussion highlights important difficulties in determining whether market misvaluation drives corporate investment. Firstly, value-maximizing managers might (optimally) respond to market mispricing by issuing equity and investing only if their firms do not face the rational cost of capital; that is, if their firms are otherwise "financially constrained." Secondly, one must recognize that firm investment and valuation might be endogenously determined when equity is mispriced. Unfortunately, studies on the real effects of market valuation often fail to distinguish between firms with and without rational demand for investment and, just as importantly, pursue testing strategies that overlook relevant simultaneity concerns.

This paper examines the impact of market (mis)valuation on corporate behavior in a way that sidesteps the difficulties just noted. To accomplish this, we exploit firm heterogeneity in tests that combine intertemporal and cross-sectional contrasts. In essence we ask: When is mispricing most likely to affect firm policies and which firms are most likely to respond to mispricing? By contrasting various managerial decisions (investment, issuance, and savings) across financially constrained and unconstrained firms, across different sectors of the economy, in and out of bubbles, our tests address concerns about identification and endogeneity, in the process of uncovering new results on the effect of equity valuation on corporate behavior.

We use the late 1990's "tech bubble" as a laboratory in which to implement our tests. ${ }^{3}$ In the context of that bubble, one might like to determine if tech firms' policies were consistent with a drive to take advantage of irrationally high stock prices. Unfortunately, this is difficult to ascertain. In the tech sector, equity prices and investment levels might seem high ex post. Yet both might be explained by unobserved, technology-driven revisions of expected profitability occurring at that time (see Pastor and Veronesi (2006)) - little can be said about a causal link between prices and investment in that sector. What is unique about the late 1990's is that the rise in technology stocks fueled a run-up in equity prices in other (non-tech) sectors of the economy (see Brooks and Katsaris

\footnotetext{
${ }^{2}$ Stein provides a novel treatment of the conflicting incentives that managers have when deciding whether to sell overvalued stocks. According to his theory, managers that face short-term (long-term) time horizons are more (less) inclined to sell stocks at prices that do not reflect firm fundamentals. Stein also considers the effect of financing frictions on the propensity to issue stock in the face of mispricing. Our results are consistent with this dimension of his theory.

${ }^{3}$ While it is inherently difficult to identify bubbles, various studies either assume or conclude that a bubble occurred around that period (e.g., Ofek and Richardson (2003), Brunnemeier and Nagel (2004), and Griffin et al. (2006)). To simplify the language, we refer to the price run-up in the tech sector during the late 1990's as the "tech bubble."
} 


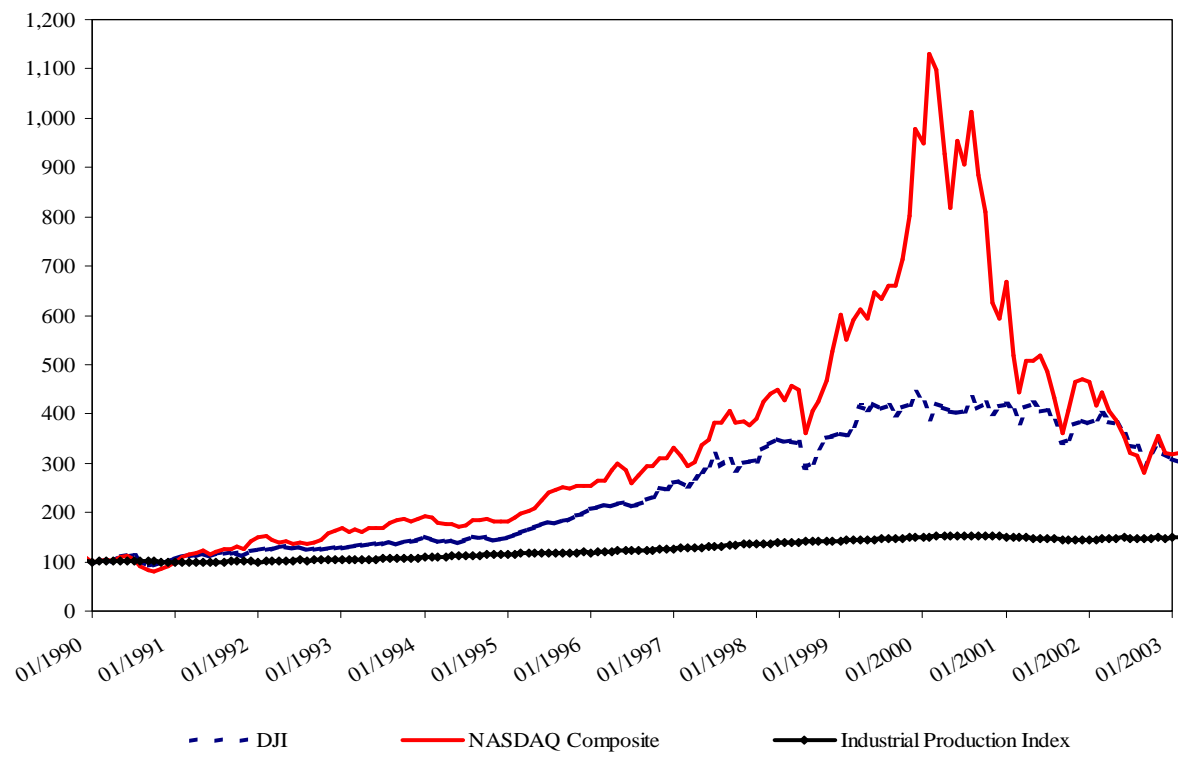

Figure 1: Major Market Indices and the Industrial Production Index (Note: Jan/1990 = 100.)

(2005a) for evidence and Caballero et al. (2006) for a theory). This notion is illustrated in Figure 1, which shows that the run-up in the Dow Jones Index during the late 1990's (and the drop in the early 2000's) closely follows that of the tech-heavy NASDAQ Index.

The run-up in the Dow Jones Index is interesting for our purposes in that virtually all firms in that index (mostly manufacturers) were, ex ante, not viewed as part of the technological revolution of the late 1990's — the Dow firms were quickly dubbed "old economy firms" as the NASDAQ rose. Indeed, research on factor productivity conducted at that time stressed that traditional manufacturers did not (nor were they expected to) significantly benefit from the innovations introduced by the tech firms (see Jorgenson and Stiroh (1999), Gordon (2000), and Stiroh (2002)). Yet, as we discuss later, their valuation appears to be influenced by the tech bubble. One potential explanation for this valuation "comovement" is that market participants (e.g., investors and financial analysts) became overoptimistic about equity investments - new and old economy stocks. Another is that traditional arbitrageurs, such as hedge funds, chose to ride the tech bubble (Brunnermeier and Nagel (2004) and Griffin et al. (2006)) and were unwilling or unable to commit funds to smaller arbitrage opportunities in non-tech sectors (Morck et al. (1990) and Shleifer and Vishny (1997)). ${ }^{4}$

Our study does not take a stand on the mechanism behind cross-sector price effects during the late 1990's. However, the context in which those effects take place help us develop our test

\footnotetext{
${ }^{4}$ Not all manufacturers should be considered as part of the old (non-tech) industrial paradigm; e.g., computer makers are classified as manufacturers. We use the U.S. Input-Output matrix and employ additional expedients to identify manufacturers with ties to the tech sector. Those manufacturers are not treated as "old economy firms" in our analysis.
} 
strategy. As a first cut at the data, rather than looking at tech firms, we study the consequences of security (mis)valuation for non-tech manufacturers during the tech bubble; i.e., we look at those firms whose 'business fundamentals' (deep technological parameters) observe no significant changes in the late 1990's. Besides minimizing concerns that shifts in fundamentals could explain our findings, by focusing on the policies of non-bubble firms we sidestep the problem of endogeneity between misvaluation and firm decisions - it is hard to argue that non-tech manufacturers' policies could burst the tech-led bubble. As a second cut, within non-bubble firms, we discriminate between those firms that ordinarily face a wedge between the cost of external funds and the marginal product of investment (financially constrained firms) and those that do not (financially unconstrained firms). As we compare firms that are likely to have excess demand for investment with those that do not, we are able to gauge whether firms act on mispricing when doing so is consistent with optimizing behavior. ${ }^{5,6}$

We design our tests to allow for direct comparisons with previous research (e.g., Blanchard et al. (1993) and Goyal and Yamada (2004)). Our baseline test consists of regressing firm investment on (1) a standard proxy for firm market value (denoted $Q^{M k t}$ ) and (2) the projection of firm market value on firm and industry "fundamentals," such as past profitability and sales growth (denoted FundQ). The basic idea behind our proposed specification is that once one expunges publicly-available information about capital productivity $(F u n d Q)$ from market prices $\left(Q^{M k t}\right)$, the remainder should have no explanatory power over firm investment, unless misvaluation affects firm decisions. As we discuss below, it is difficult to articulate a story based on alternative economic rationales (or empirical biases) capable of explaining our findings. The paper's main results can be summarized as follows.

Using a large sample of non-tech manufacturers over the 1971-2003 period, we first estimate standard investment models where investment is regressed on $Q^{M k t}$ and cash flow. These initial regressions suggest that $Q^{M k t}$ influences the investment of both financially constrained and unconstrained firms, with a stronger impact on constrained firms. We then include FundQ in the regressions. This renders $Q^{M k t}$ insignificant. Consistent with standard theory, FundQ is strongly positive and has the same impact on investment across constrained and unconstrained firms, suggesting that business fundamentals explain investment spending equally well across different types of firms. These results are not consistent with the idea that market mispricing (as measured by $Q^{M k t}$ in our specification) drives

\footnotetext{
${ }^{5}$ We use a series of standard approaches to split our sample into financially constrained and unconstrained firms; these are based on observable firm characteristics such as payout policy, size, and debt ratings. We also use a switching regression approach in which the probability that firms face financial constraints is endogenously determined with investment.

${ }^{6}$ Baker et al. (2003) also explore firm contrasts to tease out the effect misvaluation on investment (see also Polk and Sapienza (2003)). Baker et al. split firms according to a measure of "equity dependence" (the KZ Index, based on Kaplan and Zingales (1997)) and find that $Q^{M k t}$ drives the investment of equity dependent firms. Although we do not use the KZ Index, our base tests build on Baker et al. It is important to highlight that an equity dependent firm is seen in their analysis as a firm with low cash holdings, high leverage, and low profitability. In sharp contrast, the empirical characterization of a financially constrained firm in our analysis (similar to Almeida et al. (2004) and Acharya et al. (2007)) points to a firm with high cash, low leverage, and high profitability.
} 
corporate investment on average. However, our regressions do not shed light on valuation-investment dynamics when mispricing is likely to be sufficiently acute and persistent to influence corporate policies. Similar to previous studies, by averaging out time variation in the panel estimation, our initial tests fail to highlight the impact of mispricing on corporate decisions during those periods when the case for exogenous variation in equity valuation is most plausible (i.e., during bubbles).

A subsequent set of tests reveals what happens during bubbles. We add to our baseline model a dummy variable for the tech bubble period and an interaction term between that dummy and $Q^{M k t}$. The results point to a significant change in the way firms respond to mispricing. In particular, we find that while the non-fundamental component of prices has no effect on the investment of unconstrained non-tech manufacturers, the effect of mispricing on the investment of constrained non-tech manufacturers is positive and strong during the tech bubble. Our most conservative estimates imply that, during the bubble, for every one standard deviation increase in the non-fundamental component of market valuation, a constrained non-tech manufacturer's capital stock increases by $1.3 \%$ per year. Our results are novel in showing that price run-ups in one sector may improve corporate welfare in other sectors by easing constraints on the investment funding of credit-rationed firms — this without leading to wasteful overinvestment by firms that have easier access to fairly-priced funds. More broadly, our findings are consistent with recent macroeconomic theories suggesting that stock market booms shift investment spending towards financially constrained firms, stimulating corporate sector growth (see Jermann and Quadrini (2006) and Caballero et al. (2006)).

While the results discussed thus far imply the existence of a link between mispricing and investment, they do not show how mispricing affects investment. For instance, one could argue that our finding that $Q^{M k t}$ picks up significance over the bubble period may arise from concerns that the ability of FundQ to summarize fundamentals might have declined towards the end of our sample period. ${ }^{8}$ To further characterize our claims and differentiate our findings from competing explanations, we turn to the identification of the mechanism through which stock mispricing affects firm investment.

Recall, the argument we consider suggests that firms might take advantage of mispricing by issuing stock and investing the proceeds. This implies that we should observe issuance activity increasing in tandem with investment during the bubble. Accordingly, we look at whether market valuation $\left(Q^{M k t}\right)$ drives issuance over and above what is implied by the attractiveness of investment (FundQ) among non-tech manufacturers in the late 1990's. Confirming the logic of our story, we find that financially constrained firms in non-tech sectors issue more in response to mispricing during the tech bubble, while unconstrained firms in those same sectors do not. This finding is relevant because it casts doubt on the argument that investment and valuation might be correlated simply because valuation

\footnotetext{
${ }^{7}$ Alternatively, we use the NASDAQ Index as our proxy for the tech bubble.

${ }^{8}$ Of course, if this story was true, then we should see a higher coefficient for $Q^{M k t}$ during the bubble period for both constrained and unconstrained manufacturers, but this is not what we find (more on this below).
} 
gives market signals about the profitability of investment to managers - this argument implies that the stock market may not play a role in allocating funds (Dow and Gorton (1997)). In effect, we show that there exists an active financing channel underlying the link between valuation and investment.

Finally, notice that our test strategy relies on the assumption that tech firms and non-tech manufacturers differ in fundamental ways - they operate in different business paradigms. However, tech firms, just like constrained non-tech manufacturers, are typically small, pay no dividends, and have no credit ratings. One potential concern is that the investment and issuance behavior that we have documented for constrained manufacturers over the bubble might also be found in tech firms. Such similarities could call our inferences into question. Fortunately, the literature points to additional margins in which to explore our identification strategy in order to substantiate our conclusions. According to Blanchard et al. (1993), a firm whose capital stock gives rise to a pricing bubble should channel the proceeds from stock issuance towards new investment, away from cash and liquid securities - investors may burst the bubble if they observe these firms hoarding cash instead of investing. In contrast, recent work on the financial policy of constrained firms (e.g., Almeida et al. (2004)) suggests that these firms will allocate cash inflows towards holdings of cash and liquid securities constrained firms not only use funds for current investment, but also save, as internal savings allow them to invest more in the future (when investment might be more profitable).

To test these predictions, we estimate a system of simultaneous equations explaining spending and savings at the firm level. Results from these estimations reveal distinctive patterns in the allocation of funds across bubble firms and constrained non-bubble firms in the late 1990's. Firms whose actions influence the bubble (tech firms) do not allocate funds from issuance proceeds into cash savings during the bubble; instead, those funds are geared towards investment. In contrast, constrained non-bubble firms channel the issuance proceeds towards both investment and cash savings. ${ }^{9}$ These results are new to the literature, which until now has largely ignored the impact of mispricing on firm financial policies, such as cash savings behavior.

The remainder of the paper is organized as follows. In Section 2, we discuss our testing strategy, describe the data selection, and characterize our empirical specifications. Section 3 reports our results on firm investment, issuance, and savings policies over the tech bubble. Section 4 concludes.

\section{Empirical Strategy}

We first discuss how we select firms that fit our identification strategy and describe our data. Subsequently, we introduce our baseline empirical model.

\footnotetext{
${ }^{9}$ That constrained manufacturers seem to trade off the ability of investing in the late 1990's and in future years agrees with the notion that they did not overinvest during the tech bubble (when investment was not particularly attractive).
} 


\subsection{Non-Bubble Sectors During the Tech Bubble}

To implement our strategy, we seek to identify a price "run-up" or "bubble" in the market for corporate securities. We propose that one event fitting this requirement is the late 1990's tech-fueled price run-up in the major U.S. equity markets. Arguably, that phenomenon was borne out of investors' inability to gauge the marginal product of a particular set of new business technologies. For our purposes, the notable observation is that the run-up in tech stocks was mirrored - albeit on a smaller scale - in other sectors. Importantly, some of those other sectors were ex ante perceived as being outside of the tech paradigm. Our hypothesis is that the observed price run-up in those sectors were not driven by fundamentals, but derived from a contagion-type effect.

We first identify industrial sectors whose business fundamentals were likely not directly affected by the advances in telecommunications and data processing of the late 1990's (we call those sectors the "non-bubble sectors"). We then check if time series data on equity valuation $(P / E$ ratios and $Q \mathrm{~s})$ and business fundamentals (employment, product prices, sales, and profitability) from non-bubble sectors are consistent with our hypothesis that the market valuation of those sectors spiked, while fundamentals stayed constant (at historical trend levels), during the tech bubble period.

\subsubsection{Identifying Non-Bubble Sectors}

At the onset of the late 1990's wave of innovations in telecommunications, software making, and data storage and processing, a number of industrial segments were referred to as "old economy" sectors. By and large, these sectors' modi operandi were perceived to be unaltered by the technological innovations of that time. Industries falling in this category comprise an important fraction of the U.S. economy (examples are energy, steel, mining, chemicals, paper, food, and tobacco). As a first step, we look at manufacturing industries to identify non-bubble sectors (this choice is influenced by our priors and by the availability of detailed data on these industries). We recognize, however, that a number of manufacturing industries either introduced or demanded technologies that were related to the innovations of the late 1990's (see, e.g., Bond and Cummins (2000) and Stiroh (2002)). Following Bond and Cummins, we classify firms operating in SICs 355, 357, 366, 367, 369, 381, 382, and 384 as "technology-related" manufacturers. ${ }^{10}$ These industries should absorb most of the spillover effects of the technological advances of the 1990's going into the manufacturing sector.

As an extra step, we pool together the remaining manufacturing SICs and examine whether those industries' inputs come from technology and technology-related manufacturing sectors. To do this, we look at the Bureau of Economic Analysis's Benchmark Input-Output Accounts for 1997 and compute,

\footnotetext{
${ }^{10}$ These SIC codes correspond, respectively, to special industry machinery, computer and office equipment, communications equipment, electronic components and accessories, electric transmission and distribution equipment, electric industrial apparatus, miscellaneous electrical equipment, search and navigation equipment, measuring and controlling devices, and medical instruments.
} 
for each of the manufacturing industries in the U.S., the proportion of inputs that come from tech industries (SICs 481 and 737) as well as tech-related manufacturing industries (defined just above). Acting conservatively, we then drop from our sample of non-bubble sectors any industries for which inputs from tech and tech-related industries contribute more than one cent to each dollar of output sold ("tech consumers"). Likewise, we discard any industries whose output contributes with more than one cent to each dollar of output sold by tech industries ("tech suppliers"). In all, these discarded industries comprise SICs 227, 229, 348, 351, 361, 362, 365, 371, 372, 376, 379, 385, and 386. ${ }^{11}$

Finally, out of the remaining SICs, we look for those industries whose product marketing and sales - as opposed to production — might have been affected by advances in communication (e.g., online marketing). Using some judgment, we put in this category producers of apparel and textile goods (SICs 232, 233, 234, and 236), book printing and publishing (SIC 273), household appliance manufacturers (SIC 363), and toy and sports goods producers (SIC 394). ${ }^{12}$ After all these screens, we are left with 113 3-digit manufacturing SICs, which we call "non-bubble manufacturers."

\subsubsection{Valuation and Fundamentals of Non-Bubble Firms over the Bubble Period}

We hypothesize that non-bubble manufacturers did not observe significant changes in their activities over the 1990's tech bubble, but that those firms' market values may have increased relative to fundamentals in that period. In this section, we discuss the existing literature on cross-sectoral valuation and productivity effects, offering graphical evidence in support of our working hypothesis.

Valuation There is limited research on the valuation spillover effects of the technology bubble. Brooks and Katsaris (2005a) show evidence of valuation contagion effects going from the technology sector to a subset of S\&P 500 sector indices (including industrials, materials, and energy). Brooks and Katsaris (2005b) further describe trading rules based on probabilities of rallies and crashes in different sectors that lead to valuation spillover effects. They discuss profitable strategies in which investors sell stocks in sectors where the probability of a price collapse is high and buy stocks in sectors where bubbles are in their initial stages, fueling the spread of bubbles across sectors. The findings of Brunnermeier and Nagel (2004) and Griffin et al. (2006) suggest that the strategies pursued by hedge funds and large institutional investors fueled the tech bubble, sustaining it for a number of years over the late 1990's. The evidence in these papers is consistent with the scenario in which Shleifer and Vishny's (1997) "limits of arbitrage" allow for cross-sectoral price spillover effects.

\footnotetext{
${ }^{11}$ These SICs correspond, respectively, to carpets and rugs, miscellaneous textile goods, ordnance and accessories, engines and turbines, audio and video equipment, motor vehicles and equipment, aircrafts and parts, guided missiles and space vehicles parts, miscellaneous transportation equipment, ophthalmic goods, and photographic equipment.

${ }^{12}$ We also obtain data on firms that launch commercial websites during the 1994-1999 period (we thank Eliezer Fich for sharing his data). Very few industries in our final sample have more than a handful of firms launching websites during that period. Seven firms in SIC 382 (drugs) and three in SIC 331 (steel works) launch websites. We chose to keep these industries in the tests performed below, but results are unchanged if we eliminate both SICs from our sample.
} 

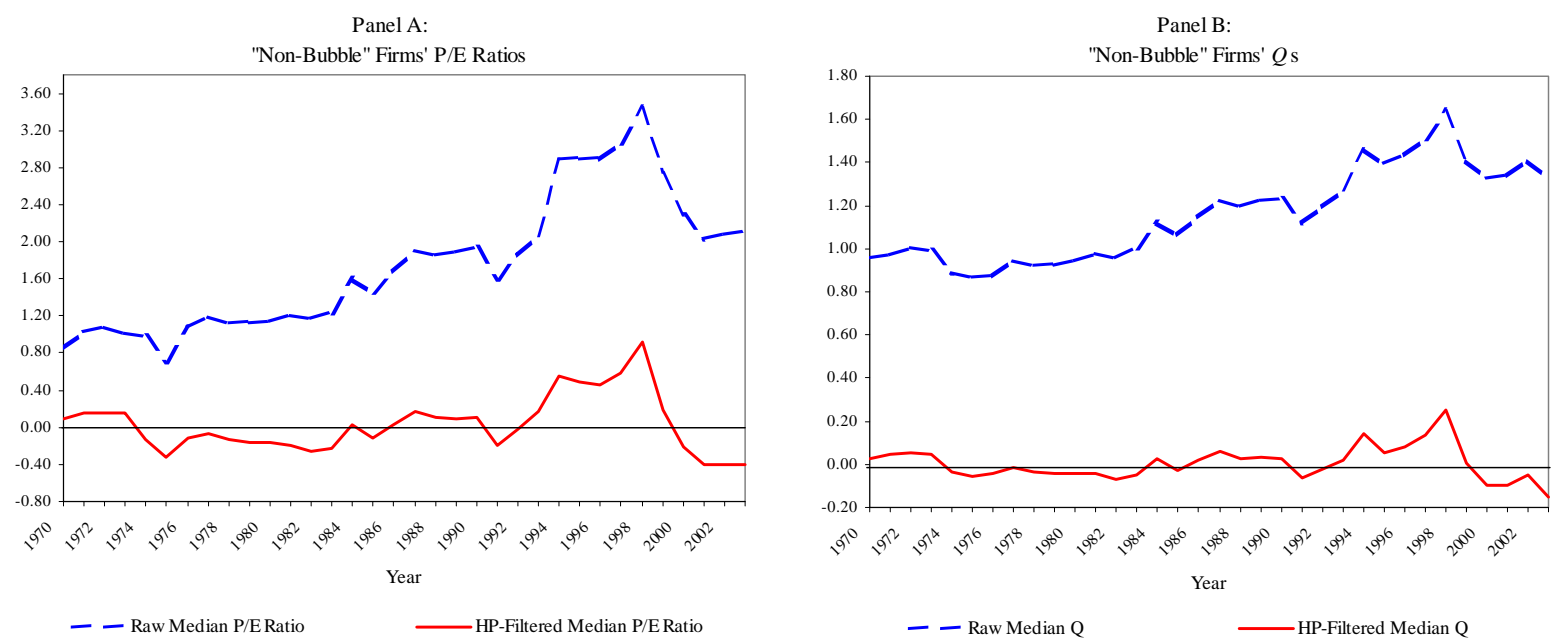

Figure 2: "Non-Bubble" Firms' Market Valuation

In a recent paper, Caballero et al. (2006) propose a model in which optimism and speculative growth in one sector of the economy leads to high asset prices in other sectors. Those authors link the sector-specific technological innovations of the late 1990's and the government surpluses observed at that time in a theory that explains how expectations about higher future availability (and lower costs) of funds may have fueled the stock market boom of the 1990's. A more behavioral explanation for valuation spillover effects in the late 1990's is that the high returns in technology stocks attracted the attention of individual investors to equity markets at a time when lower transactions costs and online trading facilitated market participation and diversification. ${ }^{13}$ As Poterba (1998) and Heaton and Lucas (1999) suggest, while experienced investors were wealthier and more risk-tolerant, newcomers in the 1990's were young wage-earners who tended to be much more risk-averse, likely investing their life savings in traditional (non-tech) sectors such as energy, chemicals, transportation, etc.

A full-blown analysis of spillover price effects during bubbles is beyond the scope of our paper. Notably, we find that virtually all of the SICs we label "non-bubble" are assigned to sector indices that Brooks and Katsaris (2005a) identify as experiencing a tech-fueled price run-up. While we don't replicate those authors' methods here, we examine whether non-bubble manufacturers' market values rose above their historical trend during the late 1990's technology bubble. To do so, we compute the median price-earnings ratio $(P / E)$ and median market-to-book ratio $(Q)$ for those firms in COMPUSTAT that operate in non-bubble manufacturing industries (as defined in Section 2.1.1) over the 1970-2003 period. We then subject those series to a Hodrick and Prescott (1997)

\footnotetext{
${ }^{13}$ According to the Survey of Consumer Finances the number of stock market participants (shareholders) in the U.S. grew from 52.3 million in 1989 to 69.3 million in 1995 - a $33 \%$ increase in just six years. Bogan (2006) estimates that the impact of lower information and transactions costs brought about by online trading on participation is equivalent to an increase in household income of some $\$ 27,000$ or an additional 2 years of education.
} 
$[\mathrm{HP}]$ decomposition, isolating their trend and transitory components. ${ }^{14}$ We plot the raw and the HP-transitory valuation series in Figure 2.

Panels A and B of Figure 2 suggest that non-tech manufacturers' $P / E$ ratios and $Q$ s soared above their historical trends in the second half of the 1990's. These value series reverted back (sharply) to their trend levels in 2000, and hovered below trend in subsequent years. These unprecedented value deviations in the non-tech manufacturing sector seem to closely mirror the rise and fall of tech stocks.

Fundamentals Next, we consider the business fundamentals of non-bubble manufacturers. One could argue that innovations in telecommunications and data processing are likely to have far-reaching consequences for firm productivity, as they could affect not only production processes, but also managerial methods, systems monitoring and logistics, corporate organization, and other intangible aspects of the firm (see Brynjolfsson and Hitt (2000)). Research on factor productivity, however, suggests that productivity gains in non-bubble sectors were not significant during the late 1990's (see, e.g., Jorgenson and Stiroh (1999), Gordon (2000), and Stiroh (2002)). More concretely, there were no noticeable shifts in productivity ("productivity acceleration") in that period for most manufacturers, but rather declines outside of the durable goods segment (where computer makers are included). Indeed, researchers are at odds as to whether gains from the technological advances of the late 1990's will ever bear fruit in older manufacturing segments (see Gordon).

We look at industry- and firm-level data on employment, prices, sales, and profitability over the last three decades to check whether these fundamental indicators change around the 1990's tech bubble. We treat these series in the same way we treated the valuation series examined above; i.e., we compile time series measures of centrality for the raw data and subject them to a HodrickPrescott decomposition. The goal is to gauge whether movements in these series could help explain the apparent increase in the valuation of non-bubble manufacturers' stocks during the late 1990's.

Panel A of Figure 3 presents plots for raw and HP-decomposed index series of industry-level employment in industries that we identify as non-bubble sectors over the 1970-2003 period. The original series on the number of employees is taken from the Bureau of Labor Statistics' Current Employment Statistics program. We normalize those industry employment indices $(1970=1)$ and compute the median estimate for each year (across industries). Panel B reports raw and HP-decomposed series on producer price indexes (PPI) over the 1970-2003 period. The raw industry series are taken from the Bureau of Labor Statistics' Report of Industries' PPI Data and subsequently normalized $(1970=$ 1). Panels $\mathrm{C}$ and D use firm-level data from COMPUSTAT. Panel C reports the median non-bubble

\footnotetext{
${ }^{14}$ Before applying the HP decomposition to these valuation series (as well as to the business fundamentals series introduced below), we check for data stationarity using the augmented Dickey-Fuller test. We difference our series until stationarity is reached. Noteworthy, aggregate series of prices and earnings are known to be cointegrated, hence their ratio is stationary (Campbell and Shiller (1987)). In our case, $P / E$ ratios are computed as the median values from annual cross-section of firms; and they too show stationarity.
} 

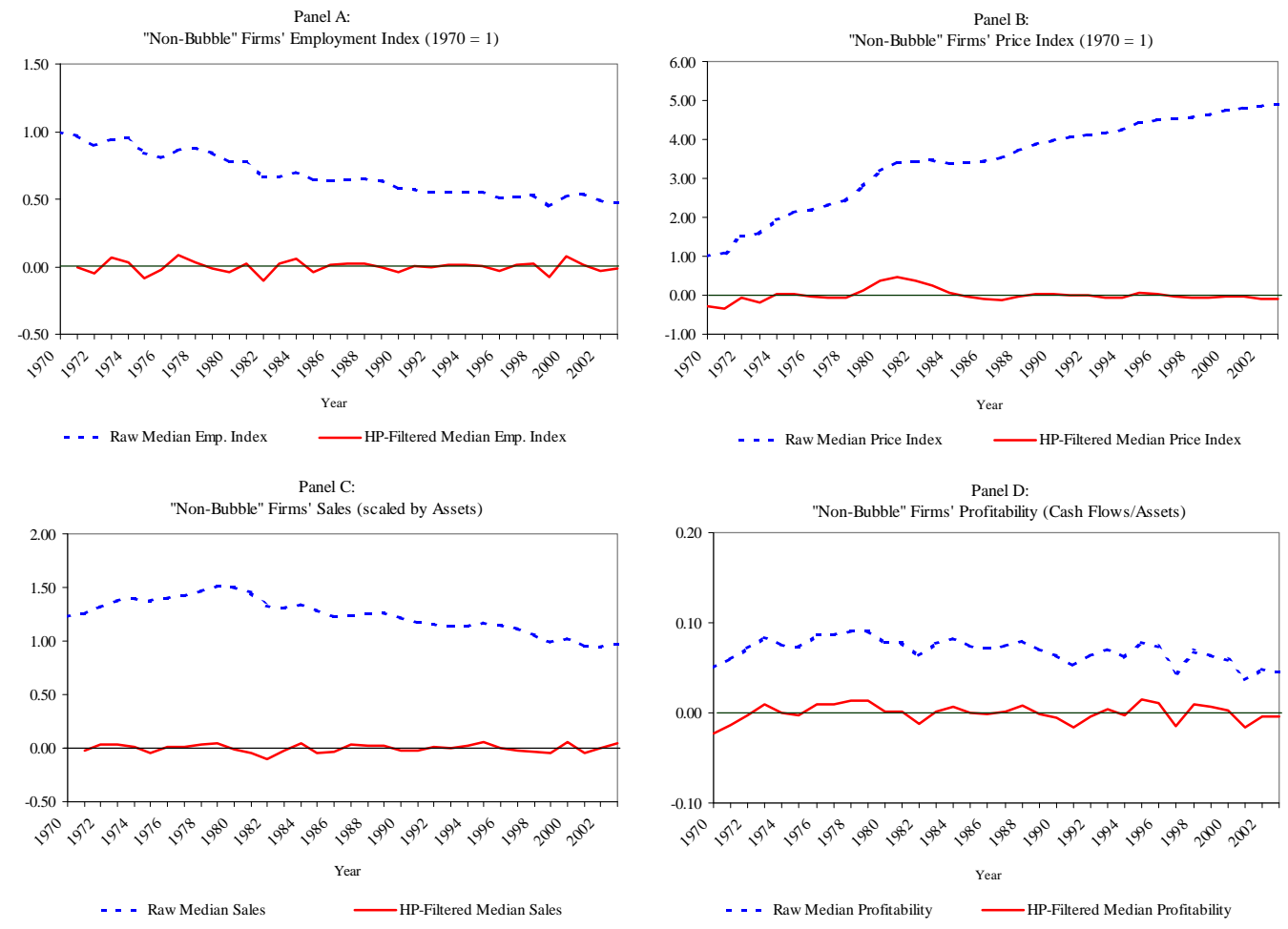

Figure 3: "Non-Bubble" Firms' Fundamentals

firms' sales (scaled by assets) and Panel D depicts profitability (cash flow over assets).

These series fail to reveal any indication of fundamental changes in production and/or profitability of the manufacturing industries that we identify as non-bubble during the late 1990's. Simply put, data from business fundamentals (in Figure 3) offer no obvious explanation for the stock price run-up of the non-tech manufacturing sector during the tech bubble (Figure 2).

\subsection{Firm Selection Criteria}

Our main analyses use firm-level data. For the tests performed in this paper, we consider a sample of firms taken from COMPUSTAT's P/S/T, Full Coverage, and Research annual files over the 1971-2003 period. We require firms to provide valid information on total assets, sales, market capitalization, cash holdings, operating income, capital expenditures, and plant, property and equipment (fixed capital). We deflate all series to 1971 dollars.

Our data selection criteria and variable construction approach largely follows that of Baker et al. (2003), who look at the impact of equity prices on firm investment, and that of Almeida et al. (2004), who study the impact of financial constraints on savings policy. Similar to Almeida et al., we discard those firm-years displaying asset or sales growth exceeding 100\% — large jumps in business fundamentals usually indicate major corporate events, such as mergers. Likewise, we also discard 
firms with annual capital expenditures exceeding $100 \%$ of the beginning-of-period capital base. Based on Gilchrist and Himmelberg (1995) and Almeida and Campello (2006), we eliminate firm-years for which fixed capital is less than $\$ 5$ million and for which the ratio of market value to book value of assets, or $Q$, exceeds 10. Those studies argue that linear investment spending models are inadequate for firms with very little capital in place and for which $Q$ is likely to be grossly mismeasured. Finally, as we also look at issuance behavior, we also exclude IPO firm-years and firm-years issuing equity in excess of $200 \%$ of their beginning-of-period equity stock.

A total of 1,943 individual firms in non-bubble manufacturing sectors remain after our basic data screens. Some of our variables require up to three lags of data, and our final sample consists of an unbalanced panel with 14,055 observations. Table 1 reports summary statistics for the variables used in our main tests. Since our sampling approach follows the literature, it is not surprising that the numbers we report in Table 1 resemble those found in related studies (e.g., Almeida et al. (2004)). In the interest of brevity, we omit discussion of the sample descriptive statistics.

$$
\overline{\text { - Table } 1 \text { about here - }}
$$

\subsection{Financially Constrained and Financially Unconstrained Firms}

Our tests require splitting firms according to measures of financing constraints. There are many plausible approaches to sorting firms into financially "constrained" and "unconstrained" categories. Since we do not have strong priors about which approach is best, we adopt multiple alternative schemes to categorize the firms in our sample.

Our basic approach is to follow the standard literature, using ex-ante financial constraint sortings that are based on firm observables, such as, payout policy, size, and debt ratings. In particular we adopt the sortings schemes discussed in Almeida et al. (2004) and Acharya et al. (2007):

- Scheme \#1: In every year over the 1971-2003 period we rank firms based on their payout ratio and assign to the financially constrained (unconstrained) category those firms in the bottom (top) three deciles of the payout distribution. We compute the payout ratio as the ratio of total distributions (dividends plus stock repurchases) to assets. ${ }^{15}$ The intuition that financially constrained firms have lower payout follows from Fazzari et al. (1988), who argue that reluctance to distribute funds is caused by a wedge between the costs of internal and external financing.

- Scheme \#2: We rank firms based on their total assets throughout the 1971-2003 period and assign to the financially constrained (unconstrained) category those firms in the bottom (top) three deciles of the asset size distribution. The rankings are again performed on an annual

\footnotetext{
${ }^{15}$ Accordingly, firms that do not pay dividends but do substantial stock repurchases are not classified as constrained.
} 
basis. This approach resembles Gilchrist and Himmelberg (1995) and Erickson and Whited (2000), who distinguish groups of financially constrained and unconstrained firms on the basis of size. The argument for size as a good measure of financial constraints is that small firms are typically young and less well known, and thus more likely to face capital market frictions.

- Scheme \#3: We retrieve data on firms' bond ratings and categorize those firms that never had their public debt rated during our sample period as financially constrained. Given that unconstrained firms may choose not to use debt financing and hence not obtain a debt rating, we only assign to the constrained subsample those firm-years that both lack a rating and report positive debt (see Faulkender and Petersen (2006)). ${ }^{16}$ Financially unconstrained firms are those whose bonds have been rated during the sample period. Related approaches for characterizing financial constraints are used by Gilchrist and Himmelberg (1995) and Cummins et al. (2006). The advantage of this measure of constraints over the former two is that it gauges the market's assessment of a firm's credit quality. The same rationale applies to the next measure.

- Scheme \#4: We retrieve data on firms' commercial paper ratings and categorize as financially constrained those firms that never display any ratings during our sample period. Observations from those firms are only assigned to the constrained subsample in years in which positive debt is reported. Firms that issued rated commercial paper at some point during the sample period are considered unconstrained. This approach follows from the work of Calomiris et al. (1995) on the characteristics of commercial paper issuers.

Table 2 reports the number of firm-years under each of the financial constraint categories used in our analysis. According to the payout scheme, for example, there are 4,232 financially constrained firm-years and 4,231 financially unconstrained firm-years. The table also shows the extent to which the four classification schemes are related. For example, out of the 4,232 firm-years classified as constrained according to the payout scheme, 2,017 are also constrained according to the size scheme, while a much smaller fraction, 509 firm-years, are classified as unconstrained. The remaining firmyears represent payout-constrained firms that are neither constrained nor unconstrained according to size. In general, there is a positive association among the four measures of financial constraints. For example, most small (large) firms lack (have) bond ratings. Also, most small (large) firms make low (high) payouts. However, the table also makes it clear that these cross-group correlations are far from perfect. This works against our tests finding consistent results across all classification schemes.

- Table 2 about here -

\footnotetext{
${ }^{16}$ Firms with no bond ratings and no debt are not considered constrained, but our results are unaffected by how we treat these firms. We use the same approach for firms with no commercial paper ratings and no debt in Scheme \#4 below.
} 
One potential drawback of the ex-ante sorting approach described above is that it does not allow the investment process to work as a determinant of the financial constraint status - the constraint categorization is exogenously given. In turn, we also use an alternative categorization approach that endogenizes the constraint status together with other variables in a structural model. The approach, borrowed from Almeida and Campello (2006), uses a switching regression model with unknown sample separation to estimate investment regressions. One advantage of this estimator is that we can simultaneously use all of the above sorting information (dividend policy, size, bond ratings, and commercial paper ratings) together with other information (such as firm value and cash flows) to categorize firms. Almeida and Campello provide a detailed description of the switching regression estimator (see also Hu and Schiantarelli (1998)). Here we give a brief summary of the methodology.

Assume that there are two different investment regimes, which we denote by "regime 1" and "regime 2." While the number of investment regimes is given, the points of structural change are not observable and are estimated together with the investment equations. The model is composed of the following system of equations (estimated simultaneously):

$$
\begin{gathered}
I_{1 i t}=X_{i t} \alpha_{1}+\varepsilon_{1 i t} \\
I_{2 i t}=X_{i t} \alpha_{2}+\varepsilon_{2 i t} \\
y_{i t}^{*}=Z_{i t} \phi+u_{i t} .
\end{gathered}
$$

Eqs. (1) and (2) are the structural equations of the system; they are essentially two different versions of our baseline investment model, Eq. (5) below. Let $X_{i t}$ be the vector of explanatory variables, and $\alpha$ be the vector of coefficients that relates the variables in $X$ to investment $I_{1 i t}$ and $I_{2 i t}$. Differential investment behavior across firms in regime 1 and regime 2 is captured by differences between $\alpha_{1}$ and $\alpha_{2}$. Eq. (3) is the selection equation that establishes the firm's likelihood of being in regime 1 or regime 2 . The vector $Z_{i t}$ contains the determinants of a firm's propensity of being in either regime. Observed investment is given by:

$$
\begin{aligned}
& I_{i t}=I_{1 i t} \text { if } y_{i t}^{*}<0 \\
& I_{i t}=I_{2 i t} \text { if } y_{i t}^{*} \geq 0,
\end{aligned}
$$

where $y_{i t}^{*}$ is a latent variable that gauges the likelihood that the firm is in the first or the second regime.

The parameters $\alpha_{1}, \alpha_{2}$, and $\phi$ are estimated via maximum likelihood. To estimate those parameters we assume that the error terms $\varepsilon_{1}, \varepsilon_{2}$, and $u$ are jointly normally distributed. Critically, the estimator's covariance matrix allows for nonzero correlation between shocks to investment and shocks to firms' characteristics - this makes the model we use an endogenous switching regression. ${ }^{17}$

\footnotetext{
${ }^{17}$ To be precise, the covariance matrix has the form $\Omega=\left[\begin{array}{ccc}\sigma_{11} & \sigma_{12} & \sigma_{1 u} \\ \sigma_{21} & \sigma_{22} & \sigma_{2 u} \\ \sigma_{u 1} & \sigma_{u 2} & 1\end{array}\right]$, where $\operatorname{var}(u)$ is normalized to 1.
} 
The extent to which investment spending differs across the two regimes and the likelihood that firms are assigned to either regime are simultaneously determined.

Finally, to identify the system we need to determine which regime is the constrained one and which regime is the unconstrained. The algorithm in Eqs. (1)-(4) creates two groups of firms that differ according to their investment behavior, but it does not tell the econometrician which firms are constrained. To achieve identification, we need to use priors about firm characteristics are associated with financial constraints. We do so, by utilizing the same four characteristics used in the ex-ante sortings (payout, size, bond ratings, and commercial paper ratings).

All of the results we report below (derived from the traditional ex-ante categorization approach) also hold for the switching regression approach. To shorten the exposition, we only tabulate the results from the switching regression estimation of the main model in the paper. Results related to the initial steps of the analysis are readily available from the authors.

\subsection{Baseline Model}

Our baseline empirical model of the valuation-investment relation is both parsimonious and fairly standard. Define Investment as the ratio of capital expenditures (COMPUSTAT item \#128) to beginning-of-period capital stock (lagged item \#8). Let $Q^{M k t}$, the proxy for market valuation, be computed as the market value of assets divided by the book value of assets, or (item \#6+ (item \#199 × item \#25) - item \#60 - item \#74) / (item \#6). CashFlow is gross operating income minus interest, taxes, and dividend payments (item \#13 - item \#15 - item \#16 - item \#19 - item \#21) divided by the beginning-of-period capital stock.

Finally, define FundQ as the projection of $Q^{M k t}$ on factors that capture information about the profitability of the firm's capital - FundQ can be seen as a compact representation of the component of market valuation that is explained by publicly observed data on capital productivity. The literature has traditionally looked at profits, investment spending, and sales growth as likely sources of information about the marginal product of capital. ${ }^{18}$ In computing FundQ, we use two lags of all of these variables. In addition, we complement our information set with firm financial data: two lags of the liquid-to-total assets ratio (liquidity), debt-to-asset ratio (leverage), and market value (capitalization). We go a step further and complement firm-level information with variables that convey information about industry conditions: two lags of industry sales growth, capital investment growth, and R\&D spending growth. ${ }^{19}$

\footnotetext{
${ }^{18}$ Examples are Barro (1990), Blundell et al. (1992), Blanchard et al. (1993), Galeotti and Schiantarelli (1994), and Goyal and Yamada (2004).

${ }^{19}$ All of the variables included in our FundQ regression model return sensible, statistically significant coefficients with the exception of the lags of industry R\&D spending. Since the estimation of the FundQ model is not particularly revealing, we omit the regression output (the tabulated results are readily available). The FundQ regression's adjusted- $R^{2}$ is $30 \%$.
} 
Our baseline model has the following form:

$$
\text { Investment }_{i, t}=\alpha_{1} Q_{i, t}^{M k t}+\alpha_{2} \text { Fund }_{i, t}+\alpha_{3} \text { CashFlow }_{i, t}+\sum_{i} \text { firm }_{i}+\sum_{t} \text { year }_{t}+\varepsilon_{i, t}
$$

where firm and year capture firm- and year-specific effects, respectively. ${ }^{20}$ Our regressions correct the error structure in Eq. (5) for heteroskedasticity using the White-Huber variance estimator.

We must be precise about our definition of mispricing. In our tests, this will refer to the component of prices that is not related to information on firm fundamentals. In particular, much of our focus is on the coefficient returned for $Q^{M k t}$ in the presence of FundQ, cf. Eq. (5). One concern is that if investors optimistically (over-)react to that information then our FundQ measure could contain what one could call mispricing. Work by Lakonishok et al. (1994) shows that this problem could be pronounced in particular firm-years (e.g., "glamour firms" observing pronounced sales growth). Since we fit the FundQ regression for our entire panel - forcing a "one-size-fits-all" loading on fundamentals - concerns that our FundQ measure can be systematically influenced by investor over-reaction to news from select groups of firm-years become less compelling. Also, note that our strategy implies a basic measure of price fundamentals: a linear extrapolation from publicly available information. One concern is that investors might use more sophisticated (non-linear) models of fundamentals to form prices. In this case, our FundQ proxy may fail to properly summarize priced fundamentals. In unreported tests, we address this concern by introducing additional log and quadratic terms of firm and industry information in our FundQ regression. This does not alter our inferences.

One potential limitation of our approach is the use of past data to proxy for the profitability of the marginal investment. In the robustness section, we follow Cummins et al. (2006) and use financial analysts' forecasts of firm profitability to compute FundQ. In addition, we also perform tests in which FundQ is computed with future realizations of the variables listed above. All results survive these alternative tests. It is therefore hard to argue that the use of expectations about the future would lead to different results in our tests, unless these are neither reflected in estimates made by financial analysts nor fall, on average, close to observed outcomes.

Before turning to the empirical section, we note that one could wonder if a more direct approach

\footnotetext{
${ }^{20}$ We use contemporaneous investment and $Q$ in Eq. (5) following the standard empirical implementation of the $Q$-theory (see Hayashi (1982)) and extensions that account for the impact of financial constraints (e.g., Fazzari et al. (1988) and Cummins et al. (2006)). One could consider the use lagged $Q$, but this is sometimes less than ideal. The theory implies that the firm should invest in lock-step with changes in $Q$ at low frequencies (annual data). The introduction of arbitrary lags in this relation may lead to misspecification. For instance, suppose that an increase in $Q$ today is associated with higher investment today (as predicted by the theory). Since investing today can make future investment less productive (one can appeal to the concavity of the production function), tomorrow's investment may be lower, biasing downward the estimate of the relation between investment and (lagged) $Q$. One can also construct arguments suggesting an upward bias in the relation between investment and lagged $Q$ (see Caballero and Leahy (1996)). To verify that our inferences do not hinge on the lag structure of the investment model, we also experiment with the use of lagged $Q$ and FundQ. This affects some of our estimates, but brings no qualitative changes to our main conclusions.
} 
to our test is to run the following regression:

$$
\text { Investment }_{i, t}=\beta_{1} \text { NonFund }_{i, t}+\beta_{2} \text { Fund }_{i, t}+\beta_{3} \text { CashFlow }_{i, t}+\sum_{i} \text { firm }_{i}+\sum_{t} \text { year }_{t}+\varepsilon_{i, t},
$$

where NonFundQ is the residual of a regression of $Q^{M k t}$ on firm fundamentals. It is easy to show that our approach is similar to this. To see how, denote FundQ, or $E[Q \mid$ Fundamentals $]$, by $P Q$. Also, denote NonFund $Q$, or $Q-E[Q \mid$ Fundamentals $]$, by $M Q$. Then, ignoring CashFlow and the firm- and year-fixed effects, we would be running the model (cf. Eq. (5) above):

$$
\text { Investment }_{i, t}=\alpha_{1} Q_{i, t}+\alpha_{2} P Q_{i, t}+\varepsilon_{i, t}
$$

while a preferred model was

$$
\text { Investment }_{i, t}=\beta_{1} M Q_{i, t}+\beta_{2} P Q_{i, t}+\varepsilon_{i, t}
$$

The question is: Are the estimates returned for $\alpha_{1}$ and $\beta_{1}$ different? No. Note that the estimate returned for $\alpha_{1}$ in Eq. (7) is equal to that of the following regression (see Greene (1993)):

$$
\text { Investment }_{i, t}=\alpha_{1} M P Q_{i, t}+\varepsilon_{i, t}
$$

where $M P Q_{i, t}$ is the same thing as $M Q_{i, t}$, since $M P Q_{i, t}=Q_{i, t}-E\left[Q_{i, t} \mid P Q\right]=Q_{i, t}-E\left[Q_{i, t} \mid E\left[Q_{i, t} \mid\right.\right.$ Fundamentals $]]=Q_{i, t}-E\left[Q_{i, t} \mid\right.$ Fundamentals $]$. The reason why we use the approach of Eq. (7) is simply that it is easier to see how we add to the existing literature: all we do is to introduce one extra variable, FundQ, keeping intact all of the other variables of the standard investment equation.

\section{Empirical Results}

\subsection{Market Valuation and Investment Spending}

\subsubsection{Base Tests}

We start our analysis with results from a compact version of Eq. (5). This standard functional form for investment spending is based on the work on financial constraints initiated with Fazzari et al. (1988) and recently used by Baker et al. (2003):

$$
\text { Investment }_{i, t}=\alpha_{1} Q_{i, t}^{M k t}+\alpha_{2} \text { CashFlow }_{i, t}+\sum_{i} \text { firm }_{i}+\sum_{t} \text { year }_{t}+\varepsilon_{i, t}
$$

The results we obtain from estimating Eq. (10) over partitions of financially constrained and unconstrained firms are reported in Table 3. The estimates suggest that market valuation $\left(Q^{M k t}\right)$ is a strong driver of investment for financially constrained firms. In other words, we find that the investment of firms that pay few or no dividends, that are small, and that have no credit ratings is 
dependent on the market valuation of their equity. In contrast, $Q^{M k t}$ is only weakly positively associated with investment spending for financially unconstrained firms. These results resemble Baker et al.'s (2003) findings on the investment-valuation sensitivity of equity dependent firms. In addition, our results on the impact of cash flows on investment resemble those in the recent literature on financial constraints: investment-cash flow sensitivities are larger for financially constrained firms, although it is significant across all sample firms.

\section{- Table 3 about here -}

Further investigation, however, leads to different inferences about the link between valuation and investment. When we include FundQ in the estimations - i.e., when we fit Eq. (5) — we find that the significance of $Q^{M k t}$ disappears. The results are reported in Table 4. The table shows that the proxy for the marginal productivity of investment, FundQ, dwarfs the impact of $Q^{M k t}$, which becomes mostly negative for unconstrained firms. The inclusion of the proxy for fundamentals boosts the explanatory power of the investment models (the regression $R^{2}$ ) by about one-third. In addition, the estimations return similar coefficients for fundamentals (FundQ) for both financially constrained and unconstrained firms. ${ }^{21}$

\section{- Table 4 about here -}

The results of Table 4 are remarkable. Firstly, note that if firm fundamentals are adequately captured and rationally priced via observables such as firm- and industry-level performance and demand measures then: (1) FundQ should have a significant, positive impact on investment, and (2) the impact of FundQ on investment should be similar across all firms. Simply put, it should be optimal for any firm (constrained or unconstrained) to invest more if innovations to its fundamentals pointed to more projects becoming positive NPV at a given cost of funds. This is exactly what we observe.

Secondly, our results suggest that market prices have not systematically driven corporate investment spending beyond its relation with fundamentals over the last 30 years. More precisely, the component of equity prices that is not spanned by a simple linear combination of observable performance variables has, on average, no bearing on investment. This may put into question some of the conclusions in the recent literature on the impact of market misvaluation on firm behavior. For example, since observed fundamentals seem to exhaust the explanatory power of market prices over investment, it is difficult to argue that managers systematically learn additional information about their firms' investment opportunities from market participants' actions, or that managers systematically take advantage of investors' irrationality by selling overvalued stocks and investing the proceeds. While our results suggest that prior inferences on the effect of prices on investment might

\footnotetext{
${ }^{21}$ Wald tests show that the FundQ coefficients are statistically identical across all sample partitions.
} 
be explained by fundamentals, they do not imply that the non-fundamental component of prices never influences real firm decisions (more on this shortly).

\subsubsection{Robustness of the Base Tests}

Before we proceed it is important that we check the robustness of the results in Table 4 (much of our subsequent analysis builds on it). The first concern one could raise is that entering FundQ in a standard investment regression might minimize the effect of $Q^{M k t}$ simply because those two variables are collinear. In a way, we use FundQ as a matter of convenience - a single proxy that synthesizes priced information from a large set of variables reflecting fundamentals. Our findings regarding $Q^{M k t}$, if robust, should also hold if we were to enter our proxies for fundamentals (profits, sales growth, etc.) directly in the regression, instead of FundQ. This is done under column 1 of Table 5. While we omit the coefficients of the 20 variables we use to capture fundamentals, it is clear that the impact of $Q^{M k t}$ on investment disappears once fundamentals are accounted for in a standard fashion. ${ }^{22}$ Another concern with our statistical approach is that FundQ is a "constructed variable," hence the standard errors in Table 4 could be severely underestimated. We check whether this observation explains the significance of FundQ by correcting the standard errors reported in Table 4 with the use of a full-fledge 2SLS estimator (i.e., the variance of the proxies for fundamentals are accounted for in the error structure of Eq. (5)). The results reported in column 2 of Table 5 dismiss this sort of concern with our original estimations. Finally, the OLS estimations of Table 4 may be biased to the extent that the regressors are correlated with the error term. While this criticism can be leveled against virtually all studies in the literature, it is worth checking whether this is a major concern for our inferences (particularly because we use current-period right-hand side variables). In column 3 of Table 5, we follow Cummins et al. (2006), who look at a comparable model and adopt a GMM estimator featuring lags 3 and 4 of the dependent and independent variables of the regression as instruments. Except for the fact that the estimates associated with $Q^{M k t}$ become even smaller (more negative), we find no qualitative differences when we use GMM to estimate Eq. (5). In all, these checks suggest that the baseline model of Table 4 leads to very consistent inferences.

$$
\text { - Table } 5 \text { about here - }
$$

The results in Tables 4 and 5 imply that the component of market valuation that is not explained by fundamentals is, on average, of no consequence for firm investment spending. Unfortunately, the design of those tests does not allow one to see how firms respond to deviations from price fundamentals when they may matter the most: during market bubbles or run-ups. It is during those periods,

\footnotetext{
${ }^{22}$ As an additional check of the collinearity story, for each of our estimations of Eq. (5) in Table 4, we measured the variance inflation factors (or VIFs) associated with $Q^{M k t}$ and FundQ. A VIF in excess of 10 should raise concerns about collinearity; however, the highest value of that statistic in our tests is only 1.6 .
} 
one could argue, that mispricing might significantly affect investment.

A number of arguments support this notion. For example, rigidities in the investment process may require deviations from fundamentals to be large and sufficiently long-lived to influence managerial decisions in meaningful ways ("hysteresis"). ${ }^{23}$ Moreover, firms may be reluctant to liquidate capital when prices fall too much. In both cases, the strict linearity of our base tests may lead us to over-reject the misvaluation-investment channel. Alternatively, one could argue that managers would be prone to take advantage of misvaluation depending on the price elasticity of demand for new share issues. If prices were to fall sharply as firms try to take advantage of misvaluation (e.g., investors may back out managers' valuation of equity based on corporate issuance policies), then misvaluation should have no observable impact on investment. In contrast, if demand were to increase sufficiently so as to absorb new equity issues at relatively high prices, then firms would be able to capitalize on mispricing if they so desired. ${ }^{24}$ If bubbles are characterized by a higher ability of firms to take advantage of misvaluation (e.g., arbitrageurs are unable or unwilling to act on mispricing à la Shleifer and Vishny (1997)), then our base analysis may lack power to detect the impact of misvaluation on investment.

In sum, one could argue that experiments designed in the spirit of our base tests might fail to capture any impact of (mis)valuation on investment simply because firms may not generally respond to small, short-lived price movements that can not be exploited. Fortunately, it is easy to modify our model to investigate this argument.

\subsubsection{The Impact of Bubbles on the Valuation-Investment Channel}

We now examine the effect of the non-fundamental component of market valuation on investment over a period of perceived widespread mispricing. To do this, we consider the tech-led bubble of the late 1990's, focusing on non-tech ("non-bubble") manufacturers. We further discriminate between those firms for which investment demand is typically constrained by financing imperfections and those that are likely to find competitively-priced funding for their investments. In other words, we again differentiate between financially constrained and unconstrained firms.

Our strategy is straightforward. For non-tech manufacturing firms, we gauge the impact of the non-fundamental component of market values during the technology bubble (i.e., the impact of $Q^{M k t}$ in the presence of FundQ) by entering in our baseline specification (Eq. (5)) a dummy variable for the 1995-1999 period (Bubble) and an interaction term for that dummy and $Q^{M k t} .{ }^{25}$ Since we add

\footnotetext{
${ }^{23}$ As a rough test of the idea that adjustment costs may create rigidities in the way investment respond to mispricing, we re-estimate Eq. (5) conditional on the ratio of fixed assets to total assets; with the premise that those adjustment costs may be lower for firms that employ less fixed capital. As it turns out, we find that $Q^{M k t}$ attracts a marginally positive coefficient for constrained firms whose ratio of fixed-to-total assets is below the sample median.

${ }^{24}$ Formally, Gilchrist et al. (2005) advance a model in which firms capitalize on bubbles. In their model, firm issuance activity drive down equity prices, yet it may not totally eliminate mispricing.

${ }^{25} \mathrm{In}$ isolating the effects of the late 1990's bubble, the last firm fiscal year we consider from COMPUSTAT is 1999. We do so because fiscal-year 2000 incorporates the bubble burst for most firms. We set the beginning of our
} 
the Bubble dummy, we drop the year dummies from Eq. (5) and model within-year error dependence using year clustering (see Rogers (1993)); errors are also corrected for heteroskedasticity. The resulting model can be written as follows:

$$
\begin{aligned}
\text { Investment }_{i, t}= & \alpha_{1} Q_{i, t}^{M k t}+\alpha_{2} \text { Fund }_{i, t}+\alpha_{3} \text { CashFlow }_{i, t} \\
& +\alpha_{4} \text { Bubble }_{t}+\alpha_{5}\left(Q_{i, t}^{M k t} \times \text { Bubble }_{t}\right)+\sum_{i} \text { firm }_{i}+\varepsilon_{i, t .} .
\end{aligned}
$$

Our focus is on whether the tech-driven bubble had a valuation effect upon the manufacturing sector; an effect that was dissociated from fundamentals and whose magnitude was significant. Accordingly, if manufacturers responded to that positive value innovation, the estimation of Eq. (11) should return a positive significant coefficient for $\alpha_{5}$. Crucially, a positive response to overvaluation in this setting would only be welfare-increasing if observed across firms that normally face financing constraints - those that otherwise would not fund positive NPV projects. For one to conclude that the tech bubble allowed mispricing to drive up investment, the sum of $\alpha_{1}$ and $\alpha_{5}$ has to be positive and significant. Our discussion emphasizes both of those coefficients.

The results from the estimation of Eq. (11) are reported in Table 6. The estimates shown in the table are robust and consistent across all of the sample partitions. They imply that the impact of mispricing on the investment of constrained firms was quite pronounced during the tech bubble period, but not outside of that period. For constrained firms, $\alpha_{1}$ is insignificant, while $\alpha_{5}$ is positive and statistically significant. Moreover, the impact of market valuation during the bubble $\left(\alpha_{1}+\alpha_{5}\right)$ is positive and statistically significant at better than the $5 \%$ test level across all constrained partitions. These results contrast sharply with those returned for financially unconstrained firms. The bubble has no impact on the relation between valuation and investment for unconstrained firms $\left(\alpha_{5} \simeq 0\right)$. Indeed, a negative relation between mispricing and investment emerges in unconstrained samples (as $\left.\alpha_{1}<0\right)$; however, that relation is economically small. Crucially, we can reject with better than $99 \%$ confidence the hypothesis that the sensitivity of investment to mispricing is the same across constrained and unconstrained firms during the tech bubble (i.e., constrained $\left(\alpha_{1}+\alpha_{5}\right)>$ unconstrained $\left.\left(\alpha_{1}+\alpha_{5}\right)\right)$. At the same time, for most partitions, that sensitivity is statistically similar across those two types of firms in the non-bubble period (or, constrained $\alpha_{1} \simeq$ unconstrained $\alpha_{1}$ ).

$$
\overline{- \text { Table } 6 \text { about here }-}
$$

run-up window in 1995 because this is the first year when the majority of manufacturing firms in our sample register $Q^{M k t}$ s that are significantly above their long-run trend (see Panel B of Figure 2). From 1995 to 1999 , the S\&P500 returns were 27, 21, 22, 25, and $12 \%$, respectively. As highlighted by White (2006), this long series of high returns is extraordinary, and likely characterizes a "market boom" if one considers that the unconditional probability of observing four consecutive years of returns in excess of $20 \%$ is only 0.004 . Our results also obtain if we alternatively take 1994 or 1996 as starting points; they become naturally weaker as we move away from that window. In later tests, we use changes in the NASDAQ Index as our bubble proxy. 
To illustrate the economic meaning of our coefficients, we consider the most conservative estimate of the marginal effect of $Q^{M k t}$ on the investment of constrained non-tech manufacturers during the tech bubble (based on commercial paper ratings; see row 4 of Table 6). For those firms, our results imply that a one standard deviation increase in the ratio of market to book value $\left(Q^{M k t}\right)$ that is not spanned by fundamentals (FundQ) leads to an increase in the yearly ratio of investment to capital stock of 0.013 , which is about $6.3 \%$ of the sample mean investment rate, or $2.4 \%$ of the sample mean total asset base (see Table 1). These magnitudes are notable, even though they are likely to underestimate the economic impact of bubbles on the valuation-investment channel for the average constrained manufacturer, who invests at the same rate of the average sample firm but has a much smaller asset base. ${ }^{26}$

In all, our estimates suggest that, during the tech bubble, variation in non-fundamental valuation allowed for new investment spending by non-bubble manufacturers facing financing constraints. In other words, run-up in equity prices allowed for positive NPV projects to be undertaken by these firms - projects that otherwise would go unfunded. In contrast, such an investment-(mis)valuation relation is not observed for firms that need not take advantage of irrationally high prices (financially unconstrained manufacturers). In particular, the relation between unconstrained manufacturers' investment and the non-fundamental component of equity values was unaffected by the bubble. These results imply that market overvaluation may ease the financing difficulties faced by credit-constrained firms - hence improving investment efficiency — without leading to wasteful overinvestment by firms that have access to fairly-priced funds. Put differently, our results suggest that what can be characterized as market pricing inefficiencies may have positive externalities across different sectors of the economy. These findings on corporate welfare have potentially important implications for economic policy-making (see Jermann and Quadrini (2006)) and point to a promising path for future research.

\subsubsection{Robustness of the Valuation-Investment Channel During Bubbles}

We perform a series of robustness checks regarding our paper's central findings. We preset those checks under three general categories.

Specification Issues While our results are robust across firm partitions, one could argue that they might arise from the simple, parsimonious nature of our empirical specification. Recent work by Erickson and Whited (2000), Gomes (2001), and Alti (2003) has attributed extant findings on the investment spending of financially constrained firms to estimation biases stemming from misspecifi-

\footnotetext{
${ }^{26}$ Notice that although Bubble attracts a negative coefficient $\left(\alpha_{4}\right)$, in order for investment to drop during the bubble, $Q^{M k t}$ has to be lower than 1 (since $-\alpha_{4} \simeq \alpha_{5}$ ). As one can see from Table 1 , however, the mean (standard deviation) of $Q^{M k t}$ is $1.363(0.813)$. Clearly, at the mean level, a one standard deviation increase in $Q^{M k t}$ more than offsets the impact of the coefficient associated with $\alpha_{4}$. The same is true even at the lowest level of empirical $Q^{M k t}$ (equal to 0.345 ).
} 


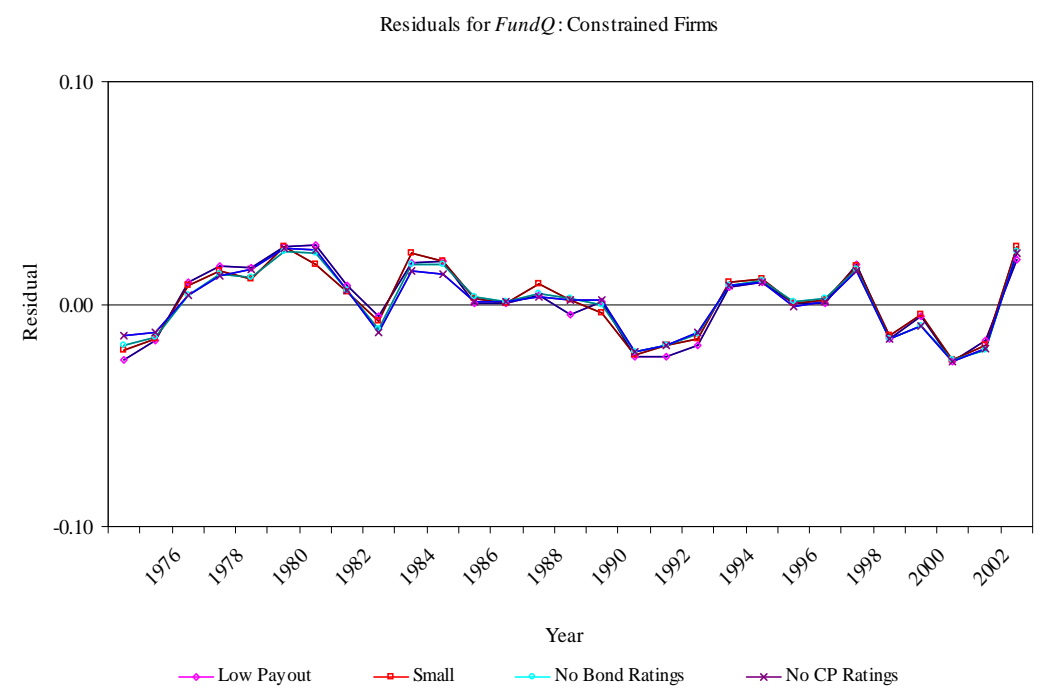

Figure 4: This figure displays annual residuals (captured by annual dummies) from a regression of Investment on FundQ across different groups of constrained manufacturing ("non-bubble") firms.

cation and mismeasurement. Objections to the Fazzari et al. (1988) investment model have focused, in particular, on the poor performance of $Q^{M k t}$ in investment equations in constrained firm samples (attenuation bias). Fortunately, our results are largely immune to these concerns. As in Baker at al. (2003), our implementation of the Fazzari et al. (1988) investment equations tend to return more positive, statistically significant coefficients for $Q^{M k t}$ in the constrained firm regressions.

Alternatively, one might argue that our inferences about the impact of mispricing during the bubble could arise from changes in our model's ability to forecast business fundamentals — hence investment demand - during bubbles. In particular, one could argue that $Q^{M k t}$ displays a comparatively greater explanatory power over investment in the 1995-1999 period (as we document) simply because of a possible decline in the ability of FundQ to summarize business fundamentals towards the end of our sample. Clearly, if this story was true, then we should see a higher coefficient for $Q^{M k t}$ during the bubble period for both constrained and unconstrained firms. This pattern does not obtain in the data (see Table 6). Yet, a simple way to check if the forecasting power of FundQ weakens over the 1995-1999 period is to look at the yearly residuals of a regression of Investment on FundQ over our sample period. Those yearly residuals are captured by the inclusion of year dummies in that regression. A plot of the residuals from each of our constrained sample regressions is displayed in Figure 4. Inspection of Figure 4 does not suggest a decline in the forecasting power of FundQ (i.e., particularly large coefficients associated with the year dummies) in the 1995-1999 window.

To more formally check whether a shift in FundQ during the 1995-1999 window could explain an 
increase in the forecasting power of $Q^{M k t}$ in that period, we augment the specification in Eq. (11) with an interaction term for Bubble and FundQ. We find that the FundQ has the same explanatory power over investment spending in and out of the tech bubble; i.e., the interaction term's estimated coefficient is small and insignificant (output omitted).

Relatedly, notice that although we presume that prices may have deviated significantly from fundamentals in the late 1990's, we use information from that period to compute FundQ in our tests. Although it is hard to anticipate how potential problems arising from this approach would bias our findings, it may be worth it checking its consequences. In an unreported table, we perform the estimations of Table 6 in a way that eliminates the influence of equity prices over the 1995-1999 window from the computation of FundQ. In short, the first-stage regression for FundQ disregards the bubble period, but the resulting loading coefficients (associated with the 20 fundamental variables) are fit on to the entire sample to construct FundQ. This leads to no changes in our conclusions.

Alternative Proxies for Fundamentals and the Tech Bubble Another potential limitation of our computation of FundQ is that the information we use regarding firm fundamentals is backwardlooking. In particular, one could argue that, even amongst manufacturing firms, the 1995-1999 period may have been characterized by shifts in fundamentals that cannot be captured by proxies such as past sales, profits, and capital growth. In that case, any variable containing forward-looking market information would perform better in a investment spending regression; hence the increase in the sensitivity of investment to $Q^{M k t}$ during the late 1990's. To verify that this story does not underlie our results, we recalculate FundQ using a forward-looking measure of firm fundamentals. Specifically, following Bond and Cummins (2001), Almeida et al. (2004), and Cummins et al. (2006), we use the projection of $Q^{M k t}$ on financial analysts' forecasts of future earnings as our FundQ proxy. As in Almeida et al., we employ the median forecast of the one-year ahead earnings scaled by lagged total assets to construct the earnings forecast measure. The earnings data come from IBES, where comprehensive coverage only starts in 1989. The results are reported in Table 7 . Although only $42 \%$ of the firm-years in our original sample provide valid observations of long-term earnings forecasts, our main results remain largely unchanged. The same conclusion applies when we include leads, i.e., future realizations, of our fundamental variables when computing FundQ (the premise is that expectations of future fundamentals are, on average, reasonably well-proxied by future values of the fundamental variables).

- Table 7 about here -

Additionally, since we use a time dummy to capture the effect of the tech bubble, one could argue that some other event in the 1995-1999 period could underlie our findings. Of course, this confounding event would need to differentially affect financially constrained and unconstrained manufacturers 
for our results to be questioned. While we were unable to identify a plausible competing explanation for our findings along those lines, we should ideally document an alternative (perhaps more direct) link between the tech bubble and the valuation-investment dynamics. We do so by replacing the 1995-1999 time indicator (Bubble) with the return on the NASDAQ Index. Notice that our story has no prediction about the impact of the tech-heavy NASDAQ Index before the 1990's, which makes it less likely that we obtain significant estimates over our long sample. On the other hand, because we may glean finer information about the price dynamics over the bubble period - something we cannot obtain with a single time dummy - these estimations could be more revealing.

The results from this test are reported in Table 8. The estimations cover the 1984 to 2003 period. Besides replacing the Bubble dummy with the December-to-December change in the NASDAQ Composite Index $(\triangle N A S D A Q)$, we add the change in the $\mathrm{S} \& \mathrm{P} 500$ Index $(\triangle S \& P 500)$ to control for changes in the overall market. ${ }^{27}$ The table shows that the coefficient returned for $Q \times \Delta N A S D A Q$ is positive and highly statistically significant in all but the size-based financially constrained partitions. At the same time, that interaction coefficient is equal to zero in all of the unconstrained partitions. These results make it more transparent that a pricing innovation in the tech sector in the late 1990's drives increases in the investment spending of financially constrained manufacturers.

$\overline{- \text { Table } 8 \text { about here }-}$

Endogenous Constraint Selection (Switching Regressions) The last issue we consider is whether our results hold when we endogenize financial constraint status. We do so following the procedure described in Section 3.2. Our selection equation (Eq. (3) above) features firm payout ratio, asset size, a dummy for the existence of bond ratings, and a dummy for commercial paper ratings as excluded instruments. In this procedure, the explanatory variables in the structural equation, that is, $Q^{M k t}$, FundQ, CashFlow, Bubble, and $Q^{M k t} \times$ Bubble, also enter the selection equation. ${ }^{28}$

Table 9 replicates the tests of Table 6 using the switching regression approach. The results reported in the new table agree with our main inferences: the impact of mispricing on the investment of constrained firms is pronounced during the tech bubble years, but not outside of that period. Once again, $\alpha_{1}$ is insignificant, while $\alpha_{5}$ is positive and statistically significant for financially constrained firms. In addition, the impact of market valuation during the bubble $\left(\alpha_{1}+\alpha_{5}\right)$ is positive and statistically significant at the $5 \%$ test level. For unconstrained firms, in contrast, the bubble has no

\footnotetext{
${ }^{27}$ We also experimented with the introduction of other market indices, macroeconomic variables, and a time trend, but these did not change our findings.

${ }^{28}$ Following $\mathrm{Hu}$ and Schiantarelli (1998), Almeida and Campello (2006) consider a number of additional variables for the selection model, such as firm age, leverage, cash holdings, and asset tangibility. The results reported below also obtain if we include similar proxies in our selection model.
} 
impact on the relation between valuation and investment $\left(\alpha_{5} \simeq 0\right.$, with $\left.\alpha_{1}<0\right)$.

$\overline{\text { - Table } 9 \text { about here - }}$

In all, the patterns we observe in manufacturing investment over the technology bubble agree with the notion that bubbles can have welfare-increasing cross-sectoral effects. In the following sections, we provide detailed evidence on the financing mechanism through which our proposed story operates.

\subsection{Market Valuation and Equity Issuance During Bubbles}

According to Fischer and Merton (1984), the mechanism through which valuation influences investment is one whereby managers act on mispricing by issuing stocks and investing the proceeds. This implies an active financing channel. We have presented evidence of mispricing-driven investment in non-bubble sectors during the late 1990's bubble, but the way in which this happens has not been fully characterized. We now take our analysis to its next logical step and look at whether mispricing also drives issuance activity over and above what is implied by the attractiveness (or fundamentals) of investment during the bubble. Again, we look at these dynamics across financially constrained and unconstrained non-bubble firms.

The literature lacks a specification for equity issuance that directly suits our analysis. As a starting point, our empirical specification amounts to using stock issuance in place of investment on the left-hand side of Eq. (11). Arguably, however, a firm's pre-existing capital structure might influence its marginal propensity to issue stocks. ${ }^{29}$ At the same time, we have weaker priors for the role of CashFlow in the issuance model. Accordingly, we replace CashFlow by the firm's lagged ratio of long term debt-to-asset ratio (Leverage) in our benchmark specification. ${ }^{30}$ Focusing on the same model dynamics considered above, we can write our empirical specification as follows:

$$
\begin{aligned}
\text { Issuance }_{i, t}= & \alpha_{1} Q_{i, t}^{M k t}+\alpha_{2} \text { Fund }_{i, t}+\alpha_{3} \text { Leverage }_{i, t-1} \\
& +\alpha_{4} \text { Bubble }_{t}+\alpha_{5}\left(Q_{i, t}^{M k t} \times \text { Bubble }_{t}\right)+\sum_{i} \text { firm }_{i}+\varepsilon_{i, t},
\end{aligned}
$$

where Issuance is computed as $(\Delta$ item \#60 $+\Delta$ item \#74 $-\Delta$ item \#36) divided by the beginningof-period equity stock (item \#60). ${ }^{31}$ As in the estimation of Eq. (11) above, we correct the error structure in Eq. (12) for heteroskedasticity and within-period error correlation.

The results from Eq. (12) are reported in Table 10. The estimations conform to our prior results on investment: they support the hypothesis that the investment of financially constrained

\footnotetext{
${ }^{29}$ The view that debt-to-asset ratios directly or indirectly affect a firm's marginal decision to issue equity is standard in the capital structure literature. For instance, while proponents of the trade-off theory enter a firm's leverage in the issuance equation directly (e.g., Hovakimian et al. (2001)), proponents of the pecking order theory do it indirectly when they enter interest payments (debt service) in "financing deficits" (e.g., Shyam-Sunder and Myers (1999)).

${ }^{30}$ Whether we use CashFlow or Leverage (or include both of these variables) in our model does not alter our inferences.

${ }^{31}$ Following Baker et al. (2003) and Fama and French (2005), our issuance proxy uses book rather than market values.
} 
non-tech manufacturers during the technology bubble was driven by an overvaluation channel. In particular, the results in Table 10 show that constrained manufacturers issued more shares in response to the non-fundamental component of market value during the late 1990's. These findings on the increased issuance-valuation sensitivity are systematic and robust, holding at better than the $5 \%$ test level across all but one of the constrained partitions (the partition based on bond ratings is significant at 12\%). The table also shows that the interplay between equity valuation and stock issuance is markedly different for financially unconstrained firms: the marginal propensity to issue stock in response to increases in $Q^{M k t}$ is generally negative for unconstrained manufacturers, and this propensity declines further during the tech bubble. When we compare estimates of issuance-valuation sensitivities of constrained and unconstrained non-tech manufacturers over the tech bubble, we find that they differ at highly statistically significant levels across all partitions; that is, constrained $\left(\alpha_{1}+\alpha_{5}\right)>$ unconstrained $\left(\alpha_{1}+\alpha_{5}\right)$ at better than the $1 \%$ test level.

Finally, our estimations yield a mostly negative relation between ex-ante leverage levels and marginal equity issuance. Our results suggest that when two firms have similar fundamentals, the firm with higher leverage may find it more costly to issue new shares, since these bear higher distress risk.

- Table 10 about here -

We stress that the prior literature on the valuation-investment relation provides only limited evidence on the impact of mispricing on issuance activity. To our knowledge, only Morck et al. (1990), Baker et al. (2003), Gilchrist et al. (2005), and Chirinko and Schaller (2006) explicitly study this connection using firm-level data. Morck et al. estimate a logit regression of the likelihood that the firm will increase its outstanding shares by more than $10 \%$ as a function of stock returns. Those authors find only marginal evidence that issuance responds to returns over and above fundamentals. Baker et al. find a positive relation between issuance and $Q^{M k t}$. We obtain similar results if we exclude firm fundamentals (FundQ) from the specification. However, as Table 10 shows, once FundQ is included, $Q^{M k t}$ no longer significantly affects issuance activity (except for constrained firms during the bubble). In a VAR framework, Gilchrist et al. find that issuance responds to increases in the dispersion of analysts' forecasts (their measure of mispricing). Chirinko and Schaller find that firms that, they argue, are more subject to mispricing (glamour firms) finance a larger proportion of their new investment via stock issuance. Those papers do not focus on the dynamics of equity prices and issuance during bubble episodes nor emphasize the role of standard financing constraints on the relation between stock mispricing and issuance. 


\subsection{The Impact of Market Valuation on Investment and Savings During Bubbles}

While we have shown that financially constrained manufacturers behave differently from unconstrained manufacturers during the technology bubble, recall that our identification strategy is based on the fact that constrained manufacturers and tech firms differ in fundamental ways - they are in different business paradigms. A concern is that those two sets of firms are similar in a number of observables (such as size), and the results we have documented for constrained manufacturers regarding investment and issuance could as well be found for tech firms. Fortunately, the literature offers guidance as to how to identify what drives differences in the real and financial policies of those two types of firms. Establishing those differences helps us further characterize our story about the effects of market misvaluation in the presence of financial constraints.

One key dimension in which to differentiate bubble and non-bubble constrained firms concerns how they handle the proceeds from the sale of stocks. According to Blanchard et al. (1993), firms whose investment prospects give rise to a pricing bubble must channel the proceeds from stock issuance towards business re-investment. For those firms, market (mis)pricing is a function of perceived investment opportunities and choosing to hoard proceeds from equity issuance can burst the bubble - saving cash signals that managers don't see business re-investing as a profitable alternative. In contrast, research on the financial policy of constrained firms shows that those firms allocate new, excess inflows towards both investment and cash savings (see Almeida et al. (2004) and Acharya et al. (2007)). According to this literature, constrained firms use excess funds for current investment but they also hoard cash - cash allows them to invest more in future periods as well. These two literatures suggest that while one should not see bubble firms saving cash out of proceeds from stock issuance during a bubble, non-bubble constrained firms should display a greater tendency towards saving cash at times when external funds are cheap and investment opportunities are unchanged.

To test our story, we identify how funds raised through equity issuance during bubbles are split between spending and savings. We do so by following the literature on corporate investment and liquidity (Fazzari et al. (1988) and Almeida et al. (2004)). The test specification builds on the benchmark model used above, but features important modifications. First, the test calls for the estimation of a system of simultaneous equations explaining spending and savings - these decisions are endogenous to each other and we treat them as such. Second, the contrast groups are no longer unconstrained versus constrained non-bubble firms, but bubble versus non-bubble constrained firms.

Define Investment and Issuance as in Sections 2.4 and 3.2. Additionally, define CashSaving as the change in the holdings of cash and other liquid securities ( $\Delta$ item $\# 1$ ) divided by lagged assets. We examine the simultaneous responses of cash savings and investment spending to equity issuance 
initiatives in and out of the bubble via a (3SLS) system of equations:

$$
\begin{aligned}
\text { CashSaving }_{i, t}= & \alpha_{1} Q_{i, t}^{\text {Mkt }}+\alpha_{2} \text { Fund }_{i, t}+\alpha_{3} \text { CashFlow }_{i, t} \\
& +\alpha_{4} \text { Issuance }_{i, t}+\alpha_{5} \text { Bubble }_{t}+\alpha_{6}\left(\text { Issuance }_{i, t} \times \text { Bubble }_{t}\right) \\
& +\alpha_{7} \text { Investment }_{i, t}+\alpha_{8} \text { CashStock }_{i, t-1}+\sum_{i} \text { firm }_{i}+\varepsilon_{i, t}^{\text {cash }}, \\
\text { Investment }_{i, t}= & \alpha_{1} Q_{i, t}^{\text {Mkt }}+\alpha_{2} \text { Fund }_{i, t}+\alpha_{3} \text { CashFlow }_{i, t} \\
& +\alpha_{4} \text { Issuance }_{i, t}+\alpha_{5} \text { Bubble }_{t}+\alpha_{6}\left(\text { Issuance }_{i, t} \times \text { Bubble }_{t}\right) \\
& +\alpha_{7} \text { CashSaving }_{i, t}+\alpha_{8} \text { CapitalStock }_{i, t-1}+\sum_{i} \text { firm }_{i}+\varepsilon_{i, t}^{i n v} .
\end{aligned}
$$

We use lagged levels of the dependent variables (which are in changes) in order to identify the system of Eqs. (13)-(14). ${ }^{32}$ Accordingly, CashStock in Eq. (13) is defined as COMPUSTAT item \#1 over item \#6, and CapitalStock in Eq. (14) is item \#8 over item \#6. ${ }^{33}$ The system allows one to gauge the marginal contribution of funds raised in the capital markets to cash savings and investment spending, accounting for the simultaneity of these decisions (note $\alpha_{7}$ in both equations). More important for our purposes is whether such contribution changes during bubble periods. This is captured by the coefficient returned for $\alpha_{6}$. Since the theory only draws clear distinctions about the cash savings behavior of non-bubble constrained firms and bubble firms during the bubble, we focus on the estimates returned for $\alpha_{6}$ from Eq. (13). Estimates from Eq. (14) are trivially identical across all firm types - issuance is positively associated with investment in and out of the bubble - and are omitted.

Results from the 3SLS estimation are reported in Table 11. The table has five rows. In the first four rows, we report the cash savings equation coefficients that are returned from each of our groups of constrained non-tech manufacturers. The fifth row reports results from the savings equation of the technology firm group (SICs 481 and 737). The estimates reveal very distinctive patterns in savings behavior across non-bubble constrained firms and bubble firms, in and out of bubbles.

Non-bubble constrained firms generally channel proceeds from issuance towards cash savings: $\alpha_{4}$ is positive and statistically significant across all partitions, except that based on bond ratings.

\footnotetext{
${ }^{32}$ The economic rationale for this instrumental set is that additional investment in an asset category should depend negatively on the initial stock of the asset due to decreasing marginal valuation associated with increasing stock levels.

${ }^{33}$ Regarding our system's identifying restrictions, one could wonder whether the instruments we use should enter directly the structural equations they instrument for. It is easy to argue that lagged capital stock (CapitalStock $\left.k_{i, t-1}\right)$ does not belong in the cash savings equation (Eq. (13)). But one concern is whether lagged cash (CashStock C $\left._{i, t-1}\right)$ should enter the investment equation (Eq. (14)). The reason for this is that financially constrained firms' investment may depend on internal resources. However, note that, as is standard in the literature, our investment equation already includes cash flow as a proxy for internal funds. It also accounts for funds from current savings and issuance activities. It is hard to argue that lagged cash has much residual information that is not already conveyed by the other variables included in Eq. (14), especially in light of the strong correlation between cash savings and cash stocks reported in Table 10 below. As an alternative approach, in unreported regressions we only used farther lags (2 and 3) of our instruments, obtaining similar results.
} 
Notably, those firms' propensity to save cash increased significantly during the bubble: $\alpha_{6}$ is positive and statistically significant across all partitions. This is pattern is not mirrored in the policies of unconstrained manufacturers. ${ }^{34}$ That constrained manufacturers save more of the proceeds from stock issuance during the tech bubble supports the hypothesis that those firms take advantage of the low cost of equity to accumulate funds for future periods, when their investment opportunity set might actually improve (recall, we argue that the underlying opportunity set of non-tech manufacturers is not affected by the tech bubble). This reveals an additional mechanism through which cross-sectoral value spillover effects have long-term welfare implications: the tech-fueled stock market run-up may have boosted otherwise constrained corporate investment in other sectors of the economy both during and after the late 1990's, through accumulated savings.

A different story is observed for firms whose actions may influence the bubble (technology firms in the late 1990's). Consistent with Blanchard et al. (1993), our estimates suggest that although technology firms display some propensity to save cash out of equity issuance inflows $\left(\alpha_{4}>0\right)$, they overtly avoided hoarding funds from the sale of stocks in their cash accounts during the bubble $\left(\alpha_{6}<0 ; \alpha_{4}+\alpha_{6} \simeq 0\right)$.

\section{- Table 11 about here -}

The results from this section conform to our priors about the impact of equity valuation on firm financial constraints. More importantly, they provide novel insights for research on the implications of market valuation. The literature has virtually ignored the impact of mispricing on firm financial policies, such as savings and issuance decisions. Our results suggest that the examination of such policies can be an interesting subject for future studies on this topic.

\section{Summary and Conclusions}

Do firms issue stock when prices seem irrationally high? What do firms do with the proceeds from the sale of overvalued stocks? Do they save or invest those funds? Is value created or destroyed in the process? These questions naturally emerge when equity prices seem to deviate from fundamental values. Firms have a natural monopoly over the supply of equity and it can be argued that managers should sell their firms' stocks whenever market discount rates are low. This line of reasoning implies a direct link between stock market valuation and firm investment spending, a link that can lead to suboptimal firm behavior (e.g., overinvestment) and may become a matter of economic policy-making

\footnotetext{
${ }^{34}$ In untabulated regressions, we estimate cash savings models using the sample of unconstrained non-tech manufacturers and find no increased propensity towards savings of issuance proceeds over the tech bubble. Similarly to results in Almeida and Campello (2007) and Acharya et al. (2007), we find that financially unconstrained manufacturers generally gear issuance proceeds towards debt reductions and dividend disbursements.
} 
(see Desai and Goolsbee (2004) and White (2006)).

Our study looks at the impact of market values on corporate investment in a way that sidesteps the issue of endogeneity between valuation and investment and that allows us to assess inefficiencies in real corporate investment. We suppose that mispricing has its roots in investors' inability to correctly forecast the impact of innovations to technology and preferences in some particular industries. Further, we recognize that once mispricing is observed it may spread to other sectors. Accordingly, in the context of a widespread price run-up (or bubble), we look for industries whose fundamentals remain unchanged, but whose market valuations have noticeably increased. We then seek to isolate, within these "non-bubble" industries, the firms that most likely face a wedge between the external cost of funds and the marginal product of investment. These "financially constrained" firms should unambiguously benefit from a decline in the cost of external financing (high stock prices).

To develop our test strategy, we use a sample of manufacturers over the 1971-2003 period and estimate standard investment equations where investment is regressed on market values $\left(Q^{M k t}\right)$. These regressions suggest that $Q^{M k t}$ influences both financially constrained and unconstrained firms' investment, but with a stronger impact on the investment spending of constrained firms. We then expunge from $Q^{M k t}$ the component that is predicted by firm "fundamentals" (such as past sales growth and profitability). This renders $Q^{M k t}$ insignificant. Subsequent tests reveal what happens during bubbles. In particular, we look at the behavior of the non-tech manufacturers in our sample during the late 1990's tech-led bubble period. We find that while the non-fundamental component of prices has no impact on the investment of financially unconstrained manufacturers during the tech bubble, the impact of mispricing on the investment of constrained manufacturers is positive and strong. Our results suggest that bubbles may have the potential effect of improving welfare by easing the constraints on investment funding of credit-rationed firms, without leading to wasteful overinvestment by firms that have access to fairly-priced funds.

While our baseline results imply the existence of a link between mispricing and investment, they do not show how mispricing affects investment. To further characterize our claims, we turn to the identification of the mechanism through which mispricing affects firm financing and investment activities. First, similarly to our analysis of investment spending, we look at whether market valuation drives equity issuance over and above what is suggested by the attractiveness of investment during the late 1990's. Consistent with the logic of our story, we find that financially constrained firms in non-bubble sectors issued more shares in response to mispricing during the tech bubble period. At the same time, unconstrained firms in those same sectors did not adjust their issuance policy to mispricing. We then seek to differentiate the behavior of constrained non-bubble firms and bubble firms. The theory suggests that bubble firms should channel the proceeds from stock issuance towards their investment activity, away from cash. In contrast, constrained non-bubble firms should 
allocate marginal cash inflows towards cash. This is exactly what we find. Our joint analysis of firms' real (investment) and financial (savings and issuance) policies are new to the literature.

The evidence of our paper suggests that market (mis)valuation can drive corporate investment, issuance, and savings policies. However, our findings are inconsistent with the notion that managers systematically issue overvalued stocks and invest in ways that transfer wealth from new to old shareholders, destroying economic value in the process. On the contrary, cross-sector spillover mispricing seems to enhance welfare by relaxing financial constraints and allowing for investment spending in valuable projects that otherwise would go underfunded. We believe these findings have interesting implications for future research in corporate finance and may also help economic policymakers. 


\section{References}

Acharya, Viral, Heitor Almeida, and Murillo Campello, 2007, "Is Cash Negative Debt? A Hedging Perspective on Corporate Financial Policies," forthcoming, Journal of Financial Intermediation.

Almeida, Heitor, and Murillo Campello, 2006, "Financing Constraints, Asset Tangibility, and Corporate Investment," forthcoming, Review of Financial Studies.

Almeida, Heitor, and Murillo Campello, 2007, "The Interplay between Financing and Investment Decisions: Evidence from Debt and Equity Issues," Working Paper, University of Illinois.

Almeida, Heitor, Murillo Campello, and Michael Weisbach, 2004, "The Cash Flow Sensitivity of Cash," Journal of Finance 59, 1777-1804.

Alti, Aydogan, 2003, "How Sensitive is Investment to Cash Flow When Financing is Frictionless?" Journal of Finance 58, 707-722.

Baker, Malcolm, Jeremy Stein, and Jeffrey Wurgler, 2003, "When Does The Market Matter? Stock Prices and The Investment of Equity-Dependent Firms," Quarterly Journal of Economics 118, 969-1005.

Barro, Robert, 1990, "The Stock Market and Investment," Review of Financial Studies 3, 115-131.

Blanchard, Olivier, Chanyong Rhee, and Lawrence Summers, 1993, "The Stock Market, Profit, and Investment," Quarterly Journal of Economics 108, 115-136.

Blundell, Richard, Stephen Bond, Michael Devereux, and Fabio Schiantarelli, 1992, "Investment and Tobin's Q: Evidence from Company Panel Data," Journal of Econometrics 51, 233-257.

Bogan,Vicki, 2006, "Stock Market Participation and the Internet," forthcoming, Journal of Financial and Quantitative Analysis.

Bond, Stephen, and Jason Cummins, 2000, "The Stock Market and Investment in the New Economy: Some Tangible Facts and Intangible Fictions," Brookings Papers on Economic Activity $1,61-124$.

Bond, Stephen, and Jason Cummins, 2001, "Noisy Share Prices and the Q Model of Investment," IFS Working Paper \#01/22.

Brooks, Chris, and Apostolos Katsaris, 2005a, "Speculative Bubbles in the S\&P 500: Was the Tech Bubble Confined to the Tech Sector?" Working Paper, City University of London.

Brooks, Chris, and Apostolos Katsaris, 2005b, "Trading Rules from Forecasting the Collapse of Speculative Bubbles for the S\&P 500 Composite Index," Journal of Business 78, 2003-2036.

Brunnermeier, Markus, and Stefan Nagel, 2004, "Hedge Funds and the Technology Bubble," Journal of Finance 59, 2013-2040.

Brynjolfsson, Erik, and Lorin Hitt, 2000, "Beyond Computation: Information Technology, Organizational Transformation and Business Performance," Journal of Economic Perspectives 14, 23-48.

Caballero, Ricardo, Emmanuel Farhi, and Mohamad Hammour, 2006, "Speculative Growth: Hints from the U.S. Economy," American Economic Review 96, 1159-1192.

Caballero, Ricardo, and John Leahy, 1996, "Fixed Costs: The Demise of Marginal q," NBER Working Paper \# 5508.

Calomiris, Charles, Charles Himmelberg, and Paul Wachtel, 1995, "Commercial Paper and Corporate Finance: A Microeconomic Perspective," Carnegie-Rochester Conference Series on Public Policy 42, 203-250. 
Campbell, John, and Robert Shiller, 1987, "Cointegration and Tests of Present Value Models," Journal of Political Economy 95, 1062-1088.

Chen, Qi, Itay Goldstein, and Wei Jiang, 2006, "Price Informativeness and Investment Sensitivity to Stock Price," forthcoming, Review of Financial Studies.

Chirinko, Robert, and Huntley Schaller, 1996, "Bubbles, Fundamentals, and Investment: A Multiple Equation Testing Strategy," Journal of Monetary Economics 39, 47-76.

Chirinko, Robert, and Huntley Schaller, 2006, "Fundamentals, Misvaluation, and Investment: The Real Story ," Working Paper, Emory University.

Cummins, Jason, Kevin Hasset, and Stephen Oliner, 2006, "Investment Behavior, Observable Expectations, and Internal Funds," American Economic Review 96, 796-810.

Desai, Mihir and Austan Goolsbee, 2004, "Investment, Overhang, and Tax Policy," Brookings Papers on Economic Activity 2, 285-338.

Dow, James, and Gary Gorton, 1997, "Stock Market Efficiency and Economic Efficiency: Is there a Connection?" Journal of Finance 52, 1087-1129.

Erickson, Timothy, and Toni Whited, 2000, "Measurement Error and the Relationship between Investment and Q," Journal of Political Economy 108, 1027-1057.

Fama, Eugene, and Kenneth French, 2005, "Financing Decisions: Who Issues Stocks?" Journal of Financial Economics 76, 549-582.

Faulkender, Michael, and Mitchell Petersen, 2006, "Does the Source of Capital Affect Capital Structure?" Review of Financial Studies 19, 45-79.

Fazzari Steven, R. Glenn Hubbard, and Bruce Petersen, 1988, "Financing Constraints and Corporate Investment," Brookings Papers on Economic Activity 1, 141-195.

Fischer, Stanley, and Robert Merton, 1984, "Macroeconomics and Finance: The Role of the Stock Market," Carnegie-Rochester Conference Series on Public Policy 21, 57-108.

Galeotti, Marzio, and Fabio Schiantarelli, 1994, "Stock Market Volatility and Investment: Do Only Fundamentals Matter?" Economica 61, 147-165.

Gilchrist, Simon, and Charles Himmelberg, 1995, "Evidence on the Role of Cash Flow for Investment," Journal of Monetary Economics 36, 541-572.

Gilchrist, Simon, Charles Himmelberg, and Gur Huberman, 2005, "Do Stock Price Bubbles Influence Corporate Investment?" Journal of Monetary Economics 52, 805-827.

Gomes, João, 2001, "Financing Investment," American Economic Review 91, 1263-1285.

Gordon, Robert, 2000, "Does the 'New Economy' Measure up to the Great Inventions of the Past?" Journal of Economic Perspectives 14, 49-74.

Goyal, Vidhan, and Takeshi Yamada, 2004, "Asset Price Shocks, Financial Constraints, and Investment: Evidence from Japan," Journal of Business 77, 175-199.

Griffin, John, Jeffrey Harris, and Selim Topaloglu, 2006, "Who Drove and Burst the Tech Bubble?" Working Paper, University of Texas.

Hayashi, Fumio, 1982, "Tobin's Marginal $q$ and Average $q$ : A Neoclassical Interpretation," Econometrica 50, 213-224.

Heaton, John, and Deborah Lucas, 1999, "Stock Prices and Fundamentals," in Ben S. Bernanke and Julio S. Rotemberg (eds.), NBER Macroeconomics Annual. Cambridge: MIT Press, 213-242. 
Hodrick, Robert, and Edward Prescott, 1997, "Postwar U.S. Business Cycles: An Empirical Investigation," Journal of Money, Credit, and Banking 29, 1-16.

Hovakimian, Armen, Tim Opler, and Sheridan Titman, 2001, "The Debt-Equity Choice," Journal of Financial and Quantitative Analysis 36, 1-24.

Hu, Xiaoqiang, and Fabio Schiantarelli, 1997, "Investment and Capital Market Imperfections: A Switching Regression Approach Using U.S. Firm Panel Data," Review of Economic and Statistics 79, 466-479.

Jermann, Urban, and Vincenzo Quadrini, 2006, "Stock Market Boom and the Productivity Gains of the 1990's," forthcoming, Journal of Monetary Economics.

Jorgenson, Dale, and Kevin Stiroh, 1999, "Information Technology and Growth," American Economic Review (Papers and Proceedings) 89, 109-115.

Kaplan, Steven, and Luigi Zingales, 1997, "Do Financing Constraints Explain why Investment is Correlated with Cash Flow?" Quarterly Journal of Economics 112, 169-215.

Lakonishok, Josef, Andrei Shleifer, and Robert Vishny, 1994, "Contrarian Investment, Extrapolation, and Risk," Journal of Finance 49, 1541-1578.

Lamont, Owen, 2000, "Investment Plans and Stock Returns," Journal of Finance 55, 2719-2745.

Morck, Randall, Andrei Shleifer, and Robert Vishny, 1990, "The Stock Market and Investment: Is the Market a Sideshow?" Brookings Papers on Economic Activity 2, 157-215.

Ofek, Eli, and Matthew Richardson, 2003, "DotCom Mania: The Rise and Fall of Internet Stock Prices," Journal of Finance 58, 1113-1138.

Pastor, Lubos, and Pietro Veronesi, 2006, "Was There a Nasdaq Bubble in the Late 1990's?" Journal of Financial Economics 81, 61-100.

Polk, Christopher, and Paola Sapienza, 2003, "The Real Effects of Investor Sentiment," Working Paper, Northwestern University.

Poterba, James, 1998, "Population Age Structure and Asset Returns: An Empirical Investigation," NBER Working Paper \# 6774.

Rogers, William, 1993, "Regression Standard Errors in Clustered Samples," Stata Technical Bulletin $13,19-23$.

Shleifer, Andrei, and Robert Vishny, 1997, "Limits of Arbitrage," Journal of Finance 52, 35-55.

Shyam-Sunder, Lakshmi, and Stewart Myers, 1999, "Testing Static Tradeoff against Pecking Order Models of Capital Structure, Journal of Financial Economics 51, 219-244.

Stein, Jeremy C., 1996, "Rational Capital Budgeting in an Irrational World," Journal of Business $69,429-455$.

Stiroh, Kevin, 2002, "Information Technology and the U.S. Productivity Revival: What Do the Industry Data Say?" American Economic Review 92, 1559-1576.

White, Eugene, 2006, "Bubbles and Busts: The 1990's in the Mirror of the 1920's," NBER Working Paper \# 12138. 


\section{Table 1. Sample Descriptive Statistics for Non-Bubble Firms}

This table displays summary statistics for the main variables used in the empirical estimations. All firm data are collected from COMPUSTAT's annual industrial tapes over the 1971-2003 period. The sample firms are from select manufacturing ("non-bubble") industries. Assets is the dollar amount of total assets (COMSPUSTAT's item \#6). FixedCapital is item \#8 divided by item \# 6. Investment is the ratio of fixed capital expenditures (item \#128) over lagged fixed capital stock (item \#8). CashFlow is gross operating income minus interest, tax, and dividend payments (item \#13 - item \#15 - item \#16 - item \#19 - item \#21) divided by the beginning-of-period capital stock. $Q^{M k t}$ is computed as the market value of assets divided by the book value of assets, or (item \#6 + (item \#24 × item \#25) - item \#60 - item \#74) / (item \#6). Issuance is net equity issuance divided by lagged equity, or the ratio of $\Delta$ item $\# 60+\Delta$ item $\# 74-\Delta$ item $\# 36$ over lagged item $\# 60$. Leverage is computed as item \#9 divided by item \#6. CashStock is item \#1 divided by item \#6. FundQ is the projection of $Q^{M k t}$ on various industry- and firm-level variables capturing the firm's marginal profitability of investment (see text for details).

\begin{tabular}{|c|c|c|c|c|c|c|}
\hline \multirow[t]{2}{*}{ Variables } & \multicolumn{6}{|c|}{ Statistics } \\
\hline & Mean & Median & Std. Dev. & $25^{t h}$ Pct. & $75^{t h}$ Pct. & Obs. \\
\hline Assets & 797.36 & 140.25 & 2259.31 & 53.44 & 552.09 & 14,055 \\
\hline FixedCapital & 0.3837 & 0.3601 & 0.1558 & 0.2666 & 0.4833 & 14,055 \\
\hline Investment & 0.1953 & 0.1764 & 0.1087 & 0.1219 & 0.2457 & 14,055 \\
\hline CashFlow & 0.2383 & 0.2162 & 0.2074 & 0.1346 & 0.3181 & 14,055 \\
\hline$Q^{M k t}$ & 1.3629 & 1.1332 & 0.8126 & 0.9044 & 1.5374 & 14,055 \\
\hline Issuance & -0.0058 & -0.0049 & 0.2441 & -0.0285 & 0.0196 & 14,055 \\
\hline Leverage & 0.2402 & 0.2300 & 0.1438 & 0.1441 & 0.3184 & 14,055 \\
\hline CashStock & 0.0761 & 0.0470 & 0.0834 & 0.0188 & 0.1041 & 14,055 \\
\hline FundQ & 1.3580 & 1.3360 & 0.4338 & 1.0664 & 1.6152 & 14,055 \\
\hline
\end{tabular}




\section{Table 2. Cross-Classification of Financial Constraint Types}

This table displays firm-year cross-classifications for the various criteria used to categorize firms as either financially constrained or unconstrained (see text for definitions). To ease visualization, we assign the letter (C) for constrained firms and (U) for unconstrained firms in each row/column. All firm data are collected from COMPUSTAT's annual industrial tapes over the 1971-2003 period. The sample firms are from select manufacturing ("non-bubble") SICs.

\begin{tabular}{|c|c|c|c|c|c|c|c|c|c|}
\hline \multirow[t]{2}{*}{ Financial Constraints Criteria } & & \multicolumn{2}{|c|}{ Div. Payout } & \multicolumn{2}{|c|}{ Firm Size } & \multicolumn{2}{|c|}{ Bond Ratings } & \multicolumn{2}{|c|}{ CP Ratings } \\
\hline & & (C) & $(\mathrm{U})$ & (C) & $(\mathrm{U})$ & (C) & $(\mathrm{U})$ & (C) & $(\mathrm{U})$ \\
\hline \multicolumn{10}{|l|}{ 1. Payout Policy } \\
\hline Constrained Firms & $(\mathrm{C})$ & 4,232 & & & & & & & \\
\hline Unconstrained Firms & $(\mathrm{U})$ & & 4,231 & & & & & & \\
\hline \multicolumn{10}{|l|}{ 2. Firm Size } \\
\hline Constrained Firms & $(\mathrm{C})$ & 2,017 & 882 & 4,231 & & & & & \\
\hline Unconstrained Firms & $(\mathrm{U})$ & 509 & 1,817 & & 4,231 & & & & \\
\hline \multicolumn{10}{|l|}{ 3. Bond Ratings } \\
\hline Constrained Firms & (C) & 2,696 & 1,878 & 3,761 & 664 & 7,180 & & & \\
\hline Unconstrained Firms & $(\mathrm{U})$ & 1,536 & 2,353 & 470 & 3,567 & & 6,875 & & \\
\hline \multicolumn{10}{|l|}{ 4. Comm. Paper Ratings } \\
\hline Constrained Firms & $(\mathrm{C})$ & 3,735 & 2,544 & 4,201 & 1,318 & 7,035 & 2,859 & 9,894 & \\
\hline Unconstrained Firms & $(\mathrm{U})$ & 497 & 1,687 & 30 & 2,913 & 145 & 4,016 & & 4,161 \\
\hline
\end{tabular}




\section{Table 3. Market Valuation and Investment Spending: Standard Investment Re- gressions}

This table displays results for OLS (with year- and firm-fixed effects) estimations of the standard Fazzari et al. (1988) investment models (Eq. (10) in the text). All firm data are collected from COMPUSTAT's annual industrial tapes over the 1971-2003 period. The sample firms are from select manufacturing ("non-bubble") SICs. Investment is the ratio of fixed capital expenditures over lagged fixed capital stock. $Q^{M k t}$ is the market value of assets divided by the book value of assets. CashFlow is gross operating income minus interest, tax, and dividend payments divided by the beginning-of-period capital stock. The estimations correct the error structure for heteroskedasticity using the White-Huber estimator. Robust standard errors are reported in parentheses.

\begin{tabular}{|c|c|c|c|c|}
\hline \multirow{2}{*}{$\begin{array}{c}\text { Dependent Variable } \\
\text { Investment }\end{array}$} & \multicolumn{2}{|c|}{ Independent Variables } & \multirow[t]{2}{*}{$R^{2}$} & \multirow[t]{2}{*}{ Obs. } \\
\hline & $Q^{M k t}$ & CashFlow & & \\
\hline \multicolumn{5}{|l|}{ Financial Constraints Criteria } \\
\hline \multicolumn{5}{|l|}{ 1. Payout Policy } \\
\hline Constrained Firms & $\begin{array}{c}0.0218^{* *} \\
(0.0076)\end{array}$ & $\begin{array}{c}0.1725^{* *} \\
(0.0165)\end{array}$ & 0.15 & 4,232 \\
\hline Unconstrained Firms & $\begin{array}{c}0.0066^{*} \\
(0.0026)\end{array}$ & $\begin{array}{c}0.1043^{* *} \\
(0.0179)\end{array}$ & 0.11 & 4,231 \\
\hline \multicolumn{5}{|l|}{ 2. Firm Size } \\
\hline Constrained Firms & $\begin{array}{c}0.0282^{* *} \\
(0.0099)\end{array}$ & $\begin{array}{c}0.1595^{* *} \\
(0.0193)\end{array}$ & 0.12 & 4,231 \\
\hline Unconstrained Firms & $\begin{array}{c}0.0021 \\
(0.0027)\end{array}$ & $\begin{array}{c}0.1492^{* *} \\
(0.0358)\end{array}$ & 0.16 & 4,231 \\
\hline \multicolumn{5}{|l|}{ 3. Bond Ratings } \\
\hline Constrained Firms & $\begin{array}{c}0.0138^{* *} \\
(0.0045)\end{array}$ & $\begin{array}{c}0.1822^{* *} \\
(0.0143)\end{array}$ & 0.12 & 7,180 \\
\hline Unconstrained Firms & $\begin{array}{c}0.0082^{* *} \\
(0.0024)\end{array}$ & $\begin{array}{c}0.1480^{* *} \\
(0.0191)\end{array}$ & 0.15 & 6,875 \\
\hline \multicolumn{5}{|l|}{ 4. Comm. Paper Ratings } \\
\hline Constrained Firms & $\begin{array}{c}0.0191^{* *} \\
(0.0040)\end{array}$ & $\begin{array}{c}0.1639^{* *} \\
(0.0125)\end{array}$ & 0.12 & 9,894 \\
\hline Unconstrained Firms & $\begin{array}{c}0.0042 \\
(0.0029)\end{array}$ & $\begin{array}{c}0.1561^{* *} \\
(0.0356)\end{array}$ & 0.18 & 4,161 \\
\hline
\end{tabular}

Note: $* *$ and $*$ indicate statistical significance at the 1-percent and 5-percent (two-tail) test levels, respectively. 


\section{Table 4. Market Valuation and Investment Spending: Controlling for Fundamen- tals}

This table displays results for OLS (with year- and firm-fixed effects) estimations of standard investment regressions with an added control for value fundamentals (FundQ) (Eq. (5) in the text). All firm data are collected from COMPUSTAT's annual industrial tapes over the 1971-2003 period. The sample firms are from select manufacturing ("non-bubble") SICs. Investment is the ratio of fixed capital expenditures over lagged fixed capital stock. $Q^{M k t}$ is the market value of assets divided by the book value of assets. FundQ is the projection of $Q^{M k t}$ on various industry- and firm-level variables capturing the firm's marginal profitability of investment (see text for details). CashFlow is gross operating income minus interest, tax, and dividend payments divided by the beginning-of-period capital stock. The estimations correct the error structure for heteroskedasticity using the White-Huber estimator. Robust standard errors are reported in parentheses.

\begin{tabular}{|c|c|c|c|c|c|}
\hline \multirow{2}{*}{$\begin{array}{c}\text { Dependent Variable } \\
\text { Investment }\end{array}$} & \multicolumn{3}{|c|}{ Independent Variables } & \multirow[t]{2}{*}{$R^{2}$} & \multirow[t]{2}{*}{ Obs. } \\
\hline & $Q^{M k t}$ & FundQ & CashFlow & & \\
\hline \multicolumn{6}{|l|}{ Financial Constraints Criteria } \\
\hline \multicolumn{6}{|l|}{ 1. Payout Policy } \\
\hline Constrained Firms & $\begin{array}{c}0.0103 \\
(0.0063)\end{array}$ & $\begin{array}{c}0.0943^{* *} \\
(0.0092)\end{array}$ & $\begin{array}{c}0.1180^{* *} \\
(0.0168)\end{array}$ & 0.19 & 4,232 \\
\hline Unconstrained Firms & $\begin{array}{c}-0.0051^{*} \\
(0.0026)\end{array}$ & $\begin{array}{r}0.0851^{* *} \\
(0.0075)\end{array}$ & $\begin{array}{c}0.0795^{* *} \\
(0.0161)\end{array}$ & 0.15 & 4,231 \\
\hline \multicolumn{6}{|l|}{ 2. Firm Size } \\
\hline Constrained Firms & $\begin{array}{c}0.0118 \\
(0.0082)\end{array}$ & $\begin{array}{c}0.0838^{* *} \\
(0.0091)\end{array}$ & $\begin{array}{c}0.1278^{* *} \\
(0.0182)\end{array}$ & 0.15 & 4,231 \\
\hline Unconstrained Firms & $\begin{array}{c}-0.0065^{*} \\
(0.0024)\end{array}$ & $\begin{array}{c}0.0754^{* *} \\
(0.0098)\end{array}$ & $\begin{array}{c}0.1155^{* *} \\
(0.0322)\end{array}$ & 0.19 & 4,231 \\
\hline \multicolumn{6}{|l|}{ 3. Bond Ratings } \\
\hline Constrained Firms & $\begin{array}{c}0.0006 \\
(0.0041)\end{array}$ & $\begin{array}{c}0.0804^{* *} \\
(0.0071)\end{array}$ & $\begin{array}{c}0.1390^{* *} \\
(0.0145)\end{array}$ & 0.15 & 7,180 \\
\hline Unconstrained Firms & $\begin{array}{l}-0.0025 \\
(0.0022)\end{array}$ & $\begin{array}{c}0.0896^{* *} \\
(0.0068)\end{array}$ & $\begin{array}{c}0.1073^{* *} \\
(0.0170)\end{array}$ & 0.19 & 6,875 \\
\hline \multicolumn{6}{|l|}{ 4. Comm. Paper Ratings } \\
\hline Constrained Firms & $\begin{array}{c}0.0060 \\
(0.0035)\end{array}$ & $\begin{array}{c}0.0829 * * \\
(0.0058)\end{array}$ & $\begin{array}{c}0.1215^{* *} \\
(0.0122)\end{array}$ & 0.16 & 9,894 \\
\hline Unconstrained Firms & $\begin{array}{c}-0.0060^{*} \\
(0.0024)\end{array}$ & $\begin{array}{c}0.0852^{* *} * \\
(0.0101)\end{array}$ & $\begin{array}{c}0.1205^{* *} \\
(0.0314)\end{array}$ & 0.22 & 4,161 \\
\hline
\end{tabular}

Note: ${ }^{* *}$ and $*$ indicate statistical significance at the 1-percent and 5-percent (two-tail) test levels, respectively. 


\section{Table 5. Market Valuation, Fundamentals, and Investment Spending: Robustness Checks}

This table displays results for OLS, 2SLS, and GMM (with year- and firm-fixed effects) estimations of standard investment regressions with an added control for value fundamentals (Eq. (5) in the text). All firm data are collected from COMPUSTAT's annual industrial tapes over the 1971-2003 period. The sample firms are from select manufacturing ("non-bubble") SICs. Investment is the ratio of fixed capital expenditures over lagged fixed capital stock. $Q^{M k t}$ is the market value of assets divided by the book value of assets. FundQ is the projection of $Q^{M k t}$ on various industry- and firm-level variables capturing the firm's marginal profitability of investment (see text for details). CashFlow is gross operating income minus interest, tax, and dividend payments divided by the beginning-of-period capital stock. The table reports only the coefficients associated with market valuation and firm fundamentals. In column 1, FundQ is replaced with a set of 20 firm- and industry-level variables capturing fundamentals. This set of variables comprise two lags of the following: firm profitability, firm investment, firm sales growth, firm liquidity, firm leverage, firm market capitalization, industry investment, industry sales growth, and industry R\&D spending. The coefficients returned for these variables are omitted; only the coefficient associated with $Q^{M k t}$ is reported. In column 2, the estimates are from a full-fledge 2SLS version of the estimations of Table 4, where standard errors are corrected for the fact that FundQ is a "constructed regressor." In column 3, the models used in Table 4 are estimated via GMM. The set of instruments used includes lags three and four of Investment, $Q^{M k t}$, and CashFlow. Robust standard errors are reported in parentheses.

\begin{tabular}{|c|c|c|c|c|c|}
\hline \multirow{2}{*}{$\begin{array}{c}\text { Dependent Variable } \\
\text { Investment }\end{array}$} & \multirow{2}{*}{$\frac{(1)}{Q^{M k t}}$} & \multicolumn{2}{|c|}{$(2)$} & \multicolumn{2}{|c|}{$(3)$} \\
\hline & & $Q^{M k t}$ & FundQ & $Q^{M k t}$ & FundQ \\
\hline \multicolumn{6}{|l|}{ Financial Constraints Criteria } \\
\hline \multicolumn{6}{|l|}{ 1. Payout Policy } \\
\hline Constrained Firms & $\begin{array}{c}0.0074 \\
(0.0057)\end{array}$ & $\begin{array}{c}0.0103 \\
(0.0235)\end{array}$ & $\begin{array}{c}0.0943^{* *} \\
(0.0190)\end{array}$ & $\begin{array}{l}-0.0681 \\
(0.0398)\end{array}$ & $\begin{array}{c}0.1204^{* *} \\
(0.0161)\end{array}$ \\
\hline Unconstrained Firms & $\begin{array}{c}-0.0083 \\
(0.0045)\end{array}$ & $\begin{array}{c}-0.0051 \\
(0.0049)\end{array}$ & $\begin{array}{c}0.0851^{* *} \\
(0.0093)\end{array}$ & $\begin{array}{l}-0.0076 \\
(0.0047)\end{array}$ & $\begin{array}{c}0.0930^{* *} \\
(0.0092)\end{array}$ \\
\hline \multicolumn{6}{|l|}{ 2. Firm Size } \\
\hline Constrained Firms & $\begin{array}{c}0.0113 \\
(0.0083)\end{array}$ & $\begin{array}{c}0.0118 \\
(0.0212)\end{array}$ & $\begin{array}{c}0.0838^{* *} \\
(0.0157)\end{array}$ & $\begin{array}{l}-0.0169 \\
(0.0177)\end{array}$ & $\begin{array}{c}0.0985^{* *} \\
(0.0131)\end{array}$ \\
\hline Unconstrained Firms & $\begin{array}{l}-0.0063 \\
(0.0033)\end{array}$ & $\begin{array}{l}-0.0065 \\
(0.0044)\end{array}$ & $\begin{array}{c}0.0754^{* *} \\
(0.0104)\end{array}$ & $\begin{array}{c}-0.0132^{* *} \\
(0.0044)\end{array}$ & $\begin{array}{r}0.0760^{* *} \\
(0.0106)\end{array}$ \\
\hline \multicolumn{6}{|l|}{ 3. Bond Ratings } \\
\hline Constrained Firms & $\begin{array}{c}0.0001 \\
(0.0051)\end{array}$ & $\begin{array}{c}0.0006 \\
(0.0110)\end{array}$ & $\begin{array}{c}0.0804^{* *} \\
(0.0109)\end{array}$ & $\begin{array}{c}-0.0250^{*} \\
(0.0114)\end{array}$ & $\begin{array}{c}0.0967^{* *} \\
(0.0101)\end{array}$ \\
\hline Unconstrained Firms & $\begin{array}{l}-0.0041 \\
(0.0037)\end{array}$ & $\begin{array}{l}-0.0025 \\
(0.0051)\end{array}$ & $\begin{array}{c}0.0896^{* *} \\
(0.0093)\end{array}$ & $\begin{array}{c}-0.0140^{* *} \\
(0.0041)\end{array}$ & $\begin{array}{r}0.0967^{* *} \\
(0.0077)\end{array}$ \\
\hline \multicolumn{6}{|l|}{ 4. Comm. Paper Ratings } \\
\hline Constrained Firms & $\begin{array}{c}0.0041 \\
(0.0042)\end{array}$ & $\begin{array}{c}0.0058 \\
(0.0115)\end{array}$ & $\begin{array}{c}0.0860^{* *} \\
(0.0096)\end{array}$ & $\begin{array}{c}-0.0240^{*} \\
(0.0099)\end{array}$ & $\begin{array}{c}0.0966^{* *} \\
(0.0080)\end{array}$ \\
\hline Unconstrained Firms & $\begin{array}{c}-0.0088^{*} \\
(0.0034)\end{array}$ & $\begin{array}{l}-0.0060 \\
(0.0047)\end{array}$ & $\begin{array}{c}0.0852^{* *} \\
(0.0115)\end{array}$ & $\begin{array}{c}-0.0112^{*} \\
(0.0046)\end{array}$ & $\begin{array}{c}0.0919 * * \\
(0.0113)\end{array}$ \\
\hline
\end{tabular}

Note: $* *$ and $*$ indicate statistical significance at the 1 -percent and 5-percent (two-tail) test levels, respectively. 


\section{Table 6. Market Valuation and Investment Spending over the Bubble}

This table displays results for OLS (with firm-fixed effects) estimations of standard investment regressions with an added control for value fundamentals (FundQ), an indicator for the the tech bubble (Bubble), and an interaction term (Eq. (11) in the text). All firm data are collected from COMPUSTAT's annual industrial tapes over the 1971-2003 period. The sample firms are from select manufacturing ("non-bubble") SICs. Investment is the ratio of fixed capital expenditures over lagged fixed capital stock. $Q^{M k t}$ is the market value of assets divided by the book value of assets. FundQ is the projection of $Q^{M k t}$ on various industry- and firm-level variables capturing the firm's marginal profitability of investment (see text for details). CashFlow is gross operating income minus interest, tax, and dividend payments divided by the beginning-of-period capital stock. Bubble is an indicator variable for the 1995-1999 period. The estimations correct the error structure for heteroskedasticity and within-period error correlation using the White-Huber estimator. Robust standard errors are reported in parentheses.

\begin{tabular}{|c|c|c|c|c|c|c|c|}
\hline \multirow{2}{*}{$\begin{array}{c}\text { Dependent Variable } \\
\text { Investment }\end{array}$} & \multicolumn{5}{|c|}{ Independent Variables } & \multirow[t]{2}{*}{$R^{2}$} & \multirow[t]{2}{*}{ Obs. } \\
\hline & $Q^{M k t}$ & FundQ & CashFlow & Bubble & $Q^{M k t} \times$ Bubble & & \\
\hline \multicolumn{8}{|l|}{ Financial Constraints Criteria } \\
\hline \multicolumn{8}{|l|}{ 1. Payout Policy } \\
\hline Constrained Firms & $\begin{array}{l}-0.0014 \\
(0.0068)\end{array}$ & $\begin{array}{c}0.0991^{* *} \\
(0.0111)\end{array}$ & $\begin{array}{c}0.1341^{* *} \\
(0.0205)\end{array}$ & $\begin{array}{l}-0.0253 \\
(0.0132)\end{array}$ & $\begin{array}{c}0.0250^{* *} \\
(0.0076)\end{array}$ & 0.15 & 4,232 \\
\hline Unconstrained Firms & $\begin{array}{c}-0.0151^{* *} \\
(0.0041)\end{array}$ & $\begin{array}{c}0.0898^{* *} \\
(0.0101)\end{array}$ & $\begin{array}{c}0.0807^{* *} \\
(0.0159)\end{array}$ & $\begin{array}{l}-0.0086 \\
0.0087)\end{array}$ & $\begin{array}{c}0.0049 \\
(0.0033)\end{array}$ & 0.08 & 4,231 \\
\hline \multicolumn{8}{|l|}{ 2. Firm Size } \\
\hline Constrained Firms & $\begin{array}{c}0.0022 \\
(0.0088)\end{array}$ & $\begin{array}{c}0.0870^{* *} \\
(0.0100)\end{array}$ & $\begin{array}{c}0.1368^{* *} \\
(0.0242)\end{array}$ & $\begin{array}{l}-0.0244 \\
(0.0183)\end{array}$ & $\begin{array}{l}0.0238^{*} \\
(0.0118)\end{array}$ & 0.13 & 4,231 \\
\hline Unconstrained Firms & $\begin{array}{c}-0.0183^{* *} \\
(0.0047)\end{array}$ & $\begin{array}{c}0.0628^{* *} \\
(0.0150)\end{array}$ & $\begin{array}{c}0.1144^{* *} \\
(0.0325)\end{array}$ & $\begin{array}{c}-0.0234^{*} \\
(0.0094)\end{array}$ & $\begin{array}{c}0.0060 \\
(0.0040)\end{array}$ & 0.08 & 4,231 \\
\hline \multicolumn{8}{|l|}{ 3. Bond Ratings } \\
\hline Constrained Firms & $\begin{array}{c}-0.0095^{*} \\
(0.0043)\end{array}$ & $\begin{array}{c}0.0847^{* *} \\
(0.0097)\end{array}$ & $\begin{array}{c}0.1474^{* *} \\
(0.0160)\end{array}$ & $\begin{array}{c}-0.0320^{* *} \\
(0.0094)\end{array}$ & $\begin{array}{c}0.0279^{* *} \\
(0.0052)\end{array}$ & 0.13 & 7,180 \\
\hline Unconstrained Firms & $\begin{array}{c}-0.0138^{* *} \\
(0.0046)\end{array}$ & $\begin{array}{c}0.0808^{* *} \\
(0.0103)\end{array}$ & $\begin{array}{c}0.1170^{* *} \\
(0.0213)\end{array}$ & $\begin{array}{l}-0.0131 \\
(0.0087)\end{array}$ & $\begin{array}{c}0.0018 \\
(0.0034)\end{array}$ & 0.10 & 6,875 \\
\hline \multicolumn{8}{|l|}{ 4. Comm. Paper Ratings } \\
\hline Constrained Firms & $\begin{array}{l}-0.0036 \\
(0.0044)\end{array}$ & $\begin{array}{c}0.0870^{* *} \\
(0.0080)\end{array}$ & $\begin{array}{c}0.1290^{* *} \\
(0.0160)\end{array}$ & $\begin{array}{c}-0.0256^{* *} \\
(0.0092)\end{array}$ & $\begin{array}{c}0.0187^{* *} \\
(0.0052)\end{array}$ & 0.12 & 9,894 \\
\hline Unconstrained Firms & $\begin{array}{c}-0.0187^{* *} \\
(0.0065)\end{array}$ & $\begin{array}{c}0.0687^{* *} \\
(0.0149)\end{array}$ & $\begin{array}{c}0.1280^{* *} \\
(0.0348)\end{array}$ & $\begin{array}{c}-0.0186^{*} \\
(0.0092)\end{array}$ & $\begin{array}{c}0.0051 \\
(0.0036)\end{array}$ & 0.09 & 4,161 \\
\hline
\end{tabular}

Note: ${ }^{* *}$ and $*$ indicate statistical significance at the 1-percent and 5-percent (two-tail) test levels, respectively. 
Table 7. Market Valuation and Investment Spending over the Bubble: Using Analyst Earnings Forecasts as an Alternative Proxy for Firm Fundamentals

This table displays results for OLS (with firm-fixed effects) estimations of investment regressions in Eq. (11) with an alternative control for firm value fundamentals $(F u n d Q)$. FundQ is now the projection of $Q^{M k t}$ on financial analysts' earnings forecasts. All firm data are collected from COMPUSTAT's annual industrial tapes over the 1989-2003 period. The sample firms are from select manufacturing ("non-bubble") SICs. Investment is the ratio of fixed capital expenditures over lagged fixed capital stock. $Q^{M k t}$ is the market value of assets divided by the book value of assets. FundQ is the projection of $Q^{M k t}$ on the median 1-year ahead forecasted value of firm earnings. CashFlow is gross operating income minus interest, tax, and dividend payments divided by the beginning-of-period capital stock. Bubble is an indicator variable for the 1995-1999 period. The estimations correct the error structure for heteroskedasticity and within-period error correlation using the White-Huber estimator. Robust standard errors are reported in parentheses.

\begin{tabular}{|c|c|c|c|c|c|c|c|}
\hline \multirow{2}{*}{$\begin{array}{c}\text { Dependent Variable } \\
\text { Investment }\end{array}$} & \multicolumn{5}{|c|}{ Independent Variables } & \multirow[t]{2}{*}{$R^{2}$} & \multirow[t]{2}{*}{ Obs. } \\
\hline & $Q^{M k t}$ & FundQ & CashFlow & Bubble & $Q^{M k t} \times$ Bubble & & \\
\hline \multicolumn{8}{|l|}{ Financial Constraints Criteria } \\
\hline \multicolumn{8}{|l|}{ 1. Payout Policy } \\
\hline Constrained Firms & $\begin{array}{l}0.0134^{*} \\
(0.0061)\end{array}$ & $\begin{array}{c}0.1395^{* *} \\
(0.0107)\end{array}$ & $\begin{array}{c}0.0634^{* *} \\
(0.0146)\end{array}$ & $\begin{array}{c}0.0002 \\
(0.0114)\end{array}$ & $\begin{array}{c}0.0156^{* *} \\
(0.0057)\end{array}$ & 0.22 & 1,756 \\
\hline Unconstrained Firms & $\begin{array}{l}-0.0090 \\
(0.0055)\end{array}$ & $\begin{array}{c}0.0781^{* *} \\
(0.0117)\end{array}$ & $\begin{array}{c}0.0581^{* *} \\
(0.0138)\end{array}$ & $\begin{array}{c}0.0160 \\
(0.0130)\end{array}$ & $\begin{array}{l}-0.0017 \\
(0.0044)\end{array}$ & 0.09 & 1,756 \\
\hline \multicolumn{8}{|l|}{ 2. Firm Size } \\
\hline Constrained Firms & $\begin{array}{l}-0.0036 \\
(0.0057)\end{array}$ & $\begin{array}{c}0.1307^{* *} \\
(0.0123)\end{array}$ & $\begin{array}{c}0.0857^{* *} \\
(0.0252)\end{array}$ & $\begin{array}{l}-0.0320 \\
(0.0236)\end{array}$ & $\begin{array}{c}0.0291^{*} \\
(0.0138)\end{array}$ & 0.18 & 1,756 \\
\hline Unconstrained Firms & $\begin{array}{c}-0.0208^{* *} \\
(0.0075)\end{array}$ & $\begin{array}{c}0.0931^{* *} \\
(0.0172)\end{array}$ & $\begin{array}{c}0.0827^{* *} \\
(0.0232)\end{array}$ & $\begin{array}{c}0.0057 \\
(0.0119)\end{array}$ & $\begin{array}{c}0.0008 \\
(0.0044)\end{array}$ & 0.13 & 1,756 \\
\hline \multicolumn{8}{|l|}{ 3. Bond Ratings } \\
\hline Constrained Firms & $\begin{array}{l}-0.0003 \\
(0.0064)\end{array}$ & $\begin{array}{c}0.1126^{* *} \\
(0.0119)\end{array}$ & $\begin{array}{c}0.0877^{* *} \\
(0.0182)\end{array}$ & $\begin{array}{l}-0.0196 \\
(0.0165)\end{array}$ & $\begin{array}{c}0.0229^{* *} \\
(0.0056)\end{array}$ & 0.17 & 2,544 \\
\hline Unconstrained Firms & $\begin{array}{l}-0.0098 \\
(0.0063)\end{array}$ & $\begin{array}{c}0.0982^{* *} \\
(0.0130)\end{array}$ & $\begin{array}{c}0.0904^{* *} \\
(0.0195)\end{array}$ & $\begin{array}{c}0.0148 \\
(0.0097)\end{array}$ & $\begin{array}{l}-0.0046 \\
(0.0039)\end{array}$ & 0.15 & 3,294 \\
\hline \multicolumn{8}{|l|}{ 4. Comm. Paper Ratings } \\
\hline Constrained Firms & $\begin{array}{c}0.0030 \\
(0.0039)\end{array}$ & $\begin{array}{c}0.1135^{* *} \\
(0.0109)\end{array}$ & $\begin{array}{c}0.0844^{* *} \\
(0.0130)\end{array}$ & $\begin{array}{l}-0.0021 \\
(0.0126)\end{array}$ & $\begin{array}{c}0.0087^{* *} \\
(0.0031)\end{array}$ & 0.17 & 4,006 \\
\hline Unconstrained Firms & $\begin{array}{c}-0.0147^{* *} \\
(0.0063)\end{array}$ & $\begin{array}{c}0.0797^{* *} \\
(0.0109)\end{array}$ & $\begin{array}{c}0.0907^{* *} \\
(0.0304)\end{array}$ & $\begin{array}{c}0.0123 \\
(0.0082)\end{array}$ & $\begin{array}{l}-0.0019 \\
(0.0037)\end{array}$ & 0.12 & 1,832 \\
\hline
\end{tabular}

Note: ${ }^{* *}$ and $*$ indicate statistical significance at the 1-percent and 5-percent (two-tail) test levels, respectively. 
Table 8. Market Valuation and Investment Spending over the Bubble: Using the NASDAQ Composite Index as an Alternative Proxy for the Tech Bubble

This table displays results for OLS (with firm-fixed effects) estimations of investment regressions in Eq. (11) with an alternative proxy for the tech bubble (Bubble). Bubble is now proxied by changes in the NASDAQ Index. All firm data are collected from COMPUSTAT's annual industrial tapes over the 1971-2003 period. The sample firms are from select manufacturing ("non-bubble") SICs. Investment is the ratio of fixed capital expenditures over lagged fixed capital stock. $Q^{M k t}$ is the market value of assets divided by the book value of assets. FundQ is the projection of $Q^{M k t}$ on various industry- and firm-level variables capturing the firm's marginal profitability of investment (see text for details). CashFlow is gross operating income minus interest, tax, and dividend payments divided by the beginning-of-period capital stock. $\triangle N A S D A Q$ is the annual change in the NASDAQ Composite Index (December to December). $\triangle S \& P 500$ is the annual change in the S\&P 500 Index. The estimations correct the error structure for heteroskedasticity and within-period error correlation using the White-Huber estimator. Robust standard errors are reported in parentheses.

\begin{tabular}{|c|c|c|c|c|c|c|c|c|}
\hline \multirow{2}{*}{$\begin{array}{c}\text { Dependent Variable } \\
\text { Investment }\end{array}$} & \multicolumn{6}{|c|}{ Independent Variables } & \multirow[t]{2}{*}{$R^{2}$} & \multirow[t]{2}{*}{ Obs. } \\
\hline & $Q^{M k t}$ & FundQ & CashFlow & $\Delta S \& P 500$ & $\triangle N A S D A Q$ & $Q^{M k t} \times \Delta N A S D A Q$ & & \\
\hline \multicolumn{9}{|l|}{ Financial Constraints Criteria } \\
\hline \multicolumn{9}{|l|}{ 1. Payout Policy } \\
\hline Constrained Firms & $\begin{array}{c}0.0017 \\
(0.0060)\end{array}$ & $\begin{array}{c}0.1028^{* *} \\
(0.0130)\end{array}$ & $\begin{array}{c}0.1194^{* *} \\
(0.0238)\end{array}$ & $\begin{array}{c}0.0286 \\
(0.0604)\end{array}$ & $\begin{array}{l}-0.0182 \\
(0.0126)\end{array}$ & $\begin{array}{c}0.0192^{* *} \\
(0.0044)\end{array}$ & 0.14 & 3,198 \\
\hline Unconstrained Firms & $\begin{array}{c}-0.0150^{* *} \\
(0.0040)\end{array}$ & $\begin{array}{c}0.0945^{* *} \\
(0.0099)\end{array}$ & $\begin{array}{c}0.0866^{* *} \\
(0.0194)\end{array}$ & $\begin{array}{c}0.0148 \\
(0.0644)\end{array}$ & $\begin{array}{c}0.0030 \\
(0.0280)\end{array}$ & $\begin{array}{c}0.0006 \\
(0.0045)\end{array}$ & 0.08 & 3,563 \\
\hline \multicolumn{9}{|l|}{ 2. Firm Size } \\
\hline Constrained Firms & $\begin{array}{c}0.0074 \\
(0.0087)\end{array}$ & $\begin{array}{c}0.0907^{* *} \\
(0.0123)\end{array}$ & $\begin{array}{c}0.1370^{* *} \\
(0.0298)\end{array}$ & $\begin{array}{c}0.0352 \\
(0.0513)\end{array}$ & $\begin{array}{c}-0.0271^{*} \\
(0.0130)\end{array}$ & $\begin{array}{c}0.0152 \\
(0.0113)\end{array}$ & 0.13 & 3,271 \\
\hline Unconstrained Firms & $\begin{array}{c}-0.0182^{* *} \\
(0.0040)\end{array}$ & $\begin{array}{c}0.0630^{* *} \\
(0.0151)\end{array}$ & $\begin{array}{c}0.0980^{* *} \\
(0.0302)\end{array}$ & $\begin{array}{l}-0.0065 \\
(0.0767)\end{array}$ & $\begin{array}{c}0.0094 \\
(0.0291)\end{array}$ & $\begin{array}{l}-0.0010 \\
(0.0037)\end{array}$ & 0.07 & 3,657 \\
\hline \multicolumn{9}{|l|}{ 3. Bond Ratings } \\
\hline Constrained Firms & $\begin{array}{l}-0.0030 \\
(0.0048)\end{array}$ & $\begin{array}{c}0.0842^{* *} \\
(0.0119)\end{array}$ & $\begin{array}{c}0.1416^{* *} \\
(0.0161)\end{array}$ & $\begin{array}{c}0.0515 \\
(0.0575)\end{array}$ & $\begin{array}{c}-0.0207^{*} \\
(0.0096)\end{array}$ & $\begin{array}{c}0.0111^{* *} \\
(0.0043)\end{array}$ & 0.12 & 5,729 \\
\hline Unconstrained Firms & $\begin{array}{c}-0.0176^{* *} \\
(0.0043)\end{array}$ & $\begin{array}{c}0.0818^{* *} \\
(0.0099)\end{array}$ & $\begin{array}{c}0.1075^{* *} \\
(0.0237)\end{array}$ & $\begin{array}{c}0.0098 \\
(0.0764)\end{array}$ & $\begin{array}{c}-0.0012 \\
(0.0236)\end{array}$ & $\begin{array}{c}0.0012 \\
(0.0025)\end{array}$ & 0.09 & 5,855 \\
\hline \multicolumn{9}{|l|}{ 4. Comm. Paper Ratings } \\
\hline Constrained Firms & $\begin{array}{l}-0.0013 \\
(0.0044)\end{array}$ & $\begin{array}{c}0.0861^{* *} \\
(0.0093)\end{array}$ & $\begin{array}{c}0.1244^{* *} \\
(0.0189)\end{array}$ & $\begin{array}{c}0.0318 \\
(0.0610)\end{array}$ & $\begin{array}{l}-0.0173 \\
(0.0101)\end{array}$ & $\begin{array}{l}0.0095^{*} \\
(0.0048)\end{array}$ & 0.11 & 7,874 \\
\hline Unconstrained Firms & $\begin{array}{c}-0.0204^{* *} \\
(0.0043)\end{array}$ & $\begin{array}{c}0.0748^{* *} \\
(0.0140)\end{array}$ & $\begin{array}{c}0.1188^{* *} \\
(0.0341)\end{array}$ & $\begin{array}{c}0.0160 \\
(0.0814)\end{array}$ & $\begin{array}{c}0.0023 \\
(0.0271)\end{array}$ & $\begin{array}{c}0.0001 \\
(0.0039)\end{array}$ & 0.09 & 3,710 \\
\hline
\end{tabular}

Note: ${ }^{* *}$ and $*$ indicate statistical significance at the 1-percent and 5-percent (two-tail) test levels, respectively. 


\section{Table 9. Market Valuation and Investment Spending over the Bubble: Switching Regressions}

This table displays results for switching regression (with firm-fixed effects) estimations of Eq. (11). These estimations allow for endogenous firm selection into financially constrained and financially unconstrained categories via maximum likelihood. The "regime selection" regression uses payout ratio, asset size, a dummy for a bond ratings, and a dummy for commercial paper ratings as selection variables to classify firms into constraint categories. All firm data are collected from COMPUSTAT's annual industrial tapes over the 1971-2003 period. The sample firms are from select manufacturing ("non-bubble") SICs. Investment is the ratio of fixed capital expenditures over lagged fixed capital stock. $Q^{M k t}$ is the market value of assets divided by the book value of assets. FundQ is the projection of $Q^{M k t}$ on various industry- and firm-level variables capturing the firm's marginal profitability of investment (see text for details). CashFlow is gross operating income minus interest, tax, and dividend payments divided by the beginning-ofperiod capital stock. Bubble is an indicator variable for the 1995-1999 period. The estimations correct the error structure for heteroskedasticity and within-period error correlation using the White-Huber estimator. Robust standard errors are reported in parentheses.

\begin{tabular}{|c|c|c|c|c|c|c|c|}
\hline \multirow{2}{*}{$\begin{array}{c}\text { Dependent Variable } \\
\text { Investment }\end{array}$} & \multicolumn{5}{|c|}{ Independent Variables } & \multirow[t]{2}{*}{$\chi^{2}$} & \multirow[t]{2}{*}{ Obs. } \\
\hline & $Q^{M k t}$ & FundQ & CashFlow & Bubble & $Q^{M k t} \times$ Bubble & & \\
\hline Constrained Firms & $\begin{array}{l}-0.0065 \\
(0.0040)\end{array}$ & $\begin{array}{c}0.0884^{* *} \\
(0.0071)\end{array}$ & $\begin{array}{c}0.1342^{* *} \\
(0.0149)\end{array}$ & $\begin{array}{c}-0.0215^{*} \\
(0.0094)\end{array}$ & $\begin{array}{c}0.0196^{* *} \\
(0.0060)\end{array}$ & 49.2 & 14,056 \\
\hline Unconstrained Firms & $\begin{array}{c}-0.0181^{* *} \\
(0.0043)\end{array}$ & $\begin{array}{c}0.0627^{* *} \\
(0.0100)\end{array}$ & $\begin{array}{c}0.1134^{* *} \\
(0.0304)\end{array}$ & $\begin{array}{c}-0.0229^{* *} \\
(0.0080)\end{array}$ & $\begin{array}{c}0.0058 \\
(0.0035)\end{array}$ & & \\
\hline
\end{tabular}

Note: ${ }^{* *}$ and $*$ indicate statistical significance at the 1-percent and 5-percent (two-tail) test levels, respectively. 


\section{Table 10. Market Valuation and Equity Issuance over the Bubble}

This table displays results for OLS (with firm-fixed effects) estimations of equity issuance regressions with a control for value fundamentals (FundQ), an indicator for the the tech bubble (Bubble), and an interaction term (Eq. (12) in the text). All firm data are collected from COMPUSTAT's annual industrial tapes over the 1971-2003 period. The sample firms are from select manufacturing ("non-bubble") SICs. Issuance is net equity issuance to lagged equity. $Q^{M k t}$ is the market value of assets divided by the book value of equity. FundQ is the projection of $Q^{M k t}$ on various industry- and firm-level variables capturing the firm's marginal profitability of investment (see text for details). Leverage is the ratio of long-term debt to total assets (this variable enters the specification in lagged form). Bubble is an indicator variable for the 1995-1999 period. The estimations correct the error structure for heteroskedasticity and within-period error correlation using the White-Huber estimator. Robust standard errors are reported in parentheses.

\begin{tabular}{|c|c|c|c|c|c|c|c|}
\hline \multirow{2}{*}{$\begin{array}{c}\text { Dependent Variable } \\
\text { Issuance } \\
\end{array}$} & \multicolumn{5}{|c|}{ Independent Variables } & \multirow[t]{2}{*}{$R^{2}$} & \multirow[t]{2}{*}{ Obs. } \\
\hline & $Q^{M k t}$ & FundQ & Leverage & Bubble & $Q^{M k t} \times$ Bubble & & \\
\hline \multicolumn{8}{|l|}{ Financial Constraints Criteria } \\
\hline \multicolumn{8}{|l|}{ 1. Payout Policy } \\
\hline Constrained Firms & $\begin{array}{c}0.0080 \\
(0.0129)\end{array}$ & $\begin{array}{c}0.0593^{* *} \\
(0.0189)\end{array}$ & $\begin{array}{c}-0.1354^{* *} \\
(0.0498)\end{array}$ & $\begin{array}{c}-0.0632 \\
(0.0345)\end{array}$ & $\begin{array}{c}0.0579^{* *} \\
(0.0210)\end{array}$ & 0.01 & 4,232 \\
\hline Unconstrained Firms & $\begin{array}{c}-0.0279^{* *} \\
(0.0059)\end{array}$ & $\begin{array}{c}0.0411^{* *} \\
(0.0142)\end{array}$ & $\begin{array}{l}-0.0559 \\
(0.0357)\end{array}$ & $\begin{array}{l}-0.0162 \\
(0.0161)\end{array}$ & $\begin{array}{l}-0.0142 \\
(0.0075)\end{array}$ & 0.02 & 4,231 \\
\hline \multicolumn{8}{|l|}{ 2. Firm Size } \\
\hline Constrained Firms & $\begin{array}{c}0.0126 \\
(0.0109)\end{array}$ & $\begin{array}{c}0.0402^{* *} \\
(0.0143)\end{array}$ & $\begin{array}{l}-0.0099 \\
(0.0420)\end{array}$ & $\begin{array}{l}-0.0427 \\
(0.0272)\end{array}$ & $\begin{array}{c}0.0374^{* *} \\
(0.0129)\end{array}$ & 0.01 & 4,231 \\
\hline Unconstrained Firms & $\begin{array}{c}-0.0156^{*} \\
(0.0063)\end{array}$ & $\begin{array}{c}0.0282 \\
(0.0159)\end{array}$ & $\begin{array}{c}-0.1599^{* *} \\
(0.0360)\end{array}$ & $\begin{array}{l}-0.0065 \\
(0.0156)\end{array}$ & $\begin{array}{c}-0.0141^{*} \\
(0.0069)\end{array}$ & 0.02 & 4,231 \\
\hline \multicolumn{8}{|l|}{ 3. Bond Ratings } \\
\hline Constrained Firms & $\begin{array}{c}0.0226^{* *} \\
(0.0059)\end{array}$ & $\begin{array}{c}0.0277^{* *} \\
(0.0094)\end{array}$ & $\begin{array}{c}0.0003 \\
(0.0292)\end{array}$ & $\begin{array}{c}-0.0041 \\
(0.0161)\end{array}$ & $\begin{array}{c}0.0154 \\
(0.0095)\end{array}$ & 0.01 & 7,180 \\
\hline Unconstrained Firms & $\begin{array}{c}-0.0246^{* *} \\
(0.0066)\end{array}$ & $\begin{array}{c}0.0716^{* *} \\
(0.0144)\end{array}$ & $\begin{array}{c}-0.1345^{* *} \\
(0.0326)\end{array}$ & $\begin{array}{l}-0.0092 \\
(0.0164)\end{array}$ & $\begin{array}{l}-0.0068 \\
(0.0079)\end{array}$ & 0.01 & 6,875 \\
\hline \multicolumn{8}{|l|}{ 4. Comm. Paper Ratings } \\
\hline Constrained Firms & $\begin{array}{c}0.0081 \\
(0.0064)\end{array}$ & $\begin{array}{c}0.0335^{* *} \\
(0.0098)\end{array}$ & $\begin{array}{c}-0.0688^{*} \\
(0.0276)\end{array}$ & $\begin{array}{l}-0.0424 \\
(0.0164)\end{array}$ & $\begin{array}{l}0.0228^{*} \\
(0.0099)\end{array}$ & 0.01 & 9,894 \\
\hline Unconstrained Firms & $\begin{array}{c}-0.0191^{* *} \\
(0.0059)\end{array}$ & $\begin{array}{c}0.0386^{*} \\
(0.0159)\end{array}$ & $\begin{array}{c}-0.0877^{*} \\
(0.0352)\end{array}$ & $\begin{array}{c}0.0059 \\
(0.0164)\end{array}$ & $\begin{array}{c}-0.0205^{* *} \\
(0.0070)\end{array}$ & 0.02 & 4,161 \\
\hline
\end{tabular}

Note: ${ }^{* *}$ and $*$ indicate statistical significance at the 1-percent and 5-percent (two-tail) test levels, respectively. 
Table 11. Market Valuation and Cash Savings Behavior over the Bubble

This table displays results for 3SLS (with firm-fixed effects) system estimations of cash savings regressions (Eq. (13) in the text). All firm data are collected from COMPUSTAT's annual industrial tapes over the 1971-2003 period. The sample firms are from select manufacturing ("non-bubble") SICs. CashSaving is the change in the holdings of cash and other liquid securities divided by lagged capital. $Q^{M k t}$ is the market value of assets divided by the book value of assets. FundQ is the projection of $Q^{M k t}$ on various industry- and firm-level variables capturing the firm's marginal profitability of investment (see text for details). CashFlow is gross operating income minus interest, tax, and dividend payments divided by the beginning-of-period capital stock. Issuance is net equity issuance to lagged equity. Bubble is an indicator variable for the 1995-1999 period. Investment is the ratio of fixed capital expenditures over lagged fixed capital stock. CashStock is the ratio of cash and liquid securities to total assets (this variable enters the specification in lagged form). Standard errors are reported in parentheses.

\begin{tabular}{|c|c|c|c|c|c|c|c|c|c|c|}
\hline \multirow{2}{*}{$\begin{array}{r}\text { Dependent Variable } \\
\text { CashSaving }\end{array}$} & \multicolumn{8}{|c|}{ Independent Variables } & \multirow[t]{2}{*}{$R^{2}$} & \multirow[t]{2}{*}{ Obs. } \\
\hline & $Q^{M k t}$ & FundQ & CashFlow & Issuance & Bubble & $\begin{array}{l}\text { Issuance } \\
\quad \times \text { Bubble } \\
\end{array}$ & Investment & CashStock & & \\
\hline \multicolumn{11}{|l|}{ Non-Bubble Constrained Firms } \\
\hline Low Payout & $\begin{array}{l}0.0092^{* *} \\
(0.0030)\end{array}$ & $\begin{array}{c}-0.0194^{*} \\
(0.0083)\end{array}$ & $\begin{array}{c}0.0476^{* *} \\
(0.0131)\end{array}$ & $\begin{array}{l}0.0111^{*} \\
(0.0054)\end{array}$ & $\begin{array}{l}-0.0032 \\
(0.0040)\end{array}$ & $\begin{array}{c}0.0263^{* *} \\
(0.0088)\end{array}$ & $\begin{array}{c}0.0952 \\
(0.0770)\end{array}$ & $\begin{array}{c}-0.4636^{* *} \\
(0.0274)\end{array}$ & 0.07 & 4,214 \\
\hline Small & $\begin{array}{c}0.0199 * * \\
(0.0031)\end{array}$ & $\begin{array}{l}-0.0117 \\
(0.0065)\end{array}$ & $\begin{array}{c}0.0421^{* *} \\
(0.0107)\end{array}$ & $\begin{array}{c}0.0153^{* *} \\
(0.0058)\end{array}$ & $\begin{array}{c}-0.0084^{*} \\
(0.0036)\end{array}$ & $\begin{array}{c}0.0526^{* *} \\
(0.0157)\end{array}$ & $\begin{array}{c}0.0287 \\
(0.0533)\end{array}$ & $\begin{array}{c}-0.5232^{* *} \\
(0.0209)\end{array}$ & 0.17 & 4,220 \\
\hline No Bond Ratings & $\begin{array}{c}0.0146^{* *} \\
(0.0020)\end{array}$ & $\begin{array}{c}-0.0101^{*} \\
(0.0046)\end{array}$ & $\begin{array}{c}0.0518^{* *} \\
(0.0083)\end{array}$ & $\begin{array}{c}0.0087 \\
(0.0049)\end{array}$ & $\begin{array}{c}-0.0115^{* *} \\
(0.0027)\end{array}$ & $\begin{array}{c}0.0355^{* *} \\
(0.0111)\end{array}$ & $\begin{array}{l}-0.0279 \\
(0.0377)\end{array}$ & $\begin{array}{c}-0.5435^{* *} \\
(0.0163)\end{array}$ & 0.19 & 7,169 \\
\hline No Comm. Paper Ratings & $\begin{array}{c}0.0135^{* *} \\
(0.0022)\end{array}$ & $\begin{array}{c}-0.0180^{* *} \\
(0.0043)\end{array}$ & $\begin{array}{c}0.0509^{* *} \\
(0.0072)\end{array}$ & $\begin{array}{c}0.0132^{* *} \\
(0.0041)\end{array}$ & $\begin{array}{c}-0.0115^{* *} \\
(0.0022)\end{array}$ & $\begin{array}{l}0.0136^{*} \\
(0.0064)\end{array}$ & $\begin{array}{c}0.0267 \\
(0.0388)\end{array}$ & $\begin{array}{c}-0.5292^{* *} \\
(0.0148)\end{array}$ & 0.17 & 9,870 \\
\hline Bubble Firms & $\begin{array}{c}0.0282^{*} \\
(0.0141)\end{array}$ & $\begin{array}{l}-0.0081 \\
(0.1114)\end{array}$ & $\begin{array}{c}0.0191 \\
(0.0569)\end{array}$ & $\begin{array}{c}0.0239 \\
(0.0130)\end{array}$ & $\begin{array}{c}0.0041 \\
(0.0090)\end{array}$ & $\begin{array}{c}-0.0309^{* *} \\
(0.0111)\end{array}$ & $\begin{array}{l}-0.4874 \\
(1.0039)\end{array}$ & $\begin{array}{c}-0.6950^{* *} \\
(0.0875)\end{array}$ & 0.01 & 1,182 \\
\hline
\end{tabular}

Note: ${ }^{* *}$ and ${ }^{*}$ indicate statistical significance at the 1-percent and 5-percent (two-tail) test levels, respectively. 